Acta Protozool. (2020) 59: 13-38

www.ejournals.eu/Acta-Protozoologica

doi:10.4467/16890027AP.20.002.12158

PROTOZOOLOGICA

Research Article

\title{
Spirostomum teres: A Long Term Study of an Anoxic-Hypolimnion Population Feeding upon Photosynthesizing Microorganisms
}

\author{
Miroslav MACEK ${ }^{1,2}$, Ximena SÁNCHEZ MEDINA ${ }^{1,3}$, Antonio PICAZO ${ }^{5}$, Dana PEŠTOVÁ ${ }^{1}$, \\ Fernando BAUTISTA REYES ${ }^{1,3}$, Jorge Ricardo MONTIEL HERNÁNDEZ ${ }^{1}$, Javier ALCOCER ${ }^{1}$, \\ Martín MERINO IBARRA ${ }^{4}$, Antonio CAMACHO
}

\author{
${ }^{1}$ Grupo de Investigación en Limnología Tropical, Universidad Nacional Autónoma de México, México \\ ${ }^{2}$ Biology Centre, v.v.i., Academy of Sciences of the Czech Republic, České Budějovice, Czech Republic \\ ${ }^{3}$ Posgrado en Ciencias del Mar y Limnología, Universidad Nacional Autónoma de México, México \\ ${ }^{4}$ Unidad Académica de Ecología y Biodiversidad Acuática, Instituto de Ciencias del Mar y Limnología, Universidad Nacional \\ Autónoma de México, Ciudad de México, México \\ ${ }^{5}$ Instituto Cavanilles de Biodiversidad y Biología Evolutiva y Departamento de Microbiología y Ecología, Campus de Burjassot, \\ Universitat de València. Burjassot (Valencia), Spain
}

\begin{abstract}
The pelagic / anoxic hypolimnion population of Spirostomum teres was investigated as a part of the long-term ciliates' monitoring (2003-2016) in an oligo- to mesotrophic monomictic hyposaline crater lake Alchichica (Puebla / Veracruz, Mexico), including an analysis of picoplankton (both heterotrophic, HPP and autotrophic, APP) and inorganic compounds of nitrogen (ammonium, nitrite, nitrate), phosphorus (dissolved reactive phosphorus, DRP) and silicon. Additionally, detailed studies of the ciliate vertical distribution and feeding activity measured upon fluorescently labelled APP (picocyanobacteria) were carried out. The results were compared with those from a neighbour freshwater crater lake La Preciosa and with a meromictic karstic lake La Cruz (Cuenca, Spain). The ciliate vertical distribution within the water column was very well defined: During the first decade, the benthic population was frequently found throughout a developing stratification of the lake. The established stratification of the lake turned the conditions favourable for the formation of an oxycline / hypolimnion population, typically, several meters below the deep chlorophyll maximum (formed basically by diatoms); the population preferred the layers without detectable dissolved oxygen. However, an observed gradient of light (PAR) could support both oxygenic and anoxygenic photosynthesis. Late stratification after deepening of the thermocline reduced the layers with $S$. teres population to a minimum apparently due to the drastic change in physicochemical conditions within a metalimnion, coupled with an oxycline, and limited to 1 to 2 meters; microstratification was found. Last years, the very bottom population disappeared or it was reduced and the late stratification $S$. teres peaks were smaller or did not appeared. Generally, S. teres oxycline / anoxic hypolimnion population was observed from June through November. Optimum picoplankton numbers in conditions that supported the ciliate growth were found: The ciliate was peaking at APP of 0.6 to $1 \times 10^{5}$ cells $\mathrm{mL}^{-1}$; the optimum of HPP was observed round $1.4 \times 10^{6}$ cells $\mathrm{mL}^{-1}$. S. teres was efficiently feeding upon picocyanobacteria in numbers of $10^{5}$ cells $\mathrm{mL}^{-1}$ reaching the clearance rate of $2000 \mathrm{~nL} \mathrm{cell}^{-1} \mathrm{~h}^{-1}$, which represented in average 130 to 210 cells cell ${ }^{-1} \mathrm{~h}^{-1}$ ingested. Feeding upon purple sulphur bacteria was observed but only during the end of the lake stable stratification when the ciliate population was already dropping. On the other hand, the volume specific clearance of $S$. teres upon picocyanobacteria $\left(10^{3} \mathrm{~h}^{-1}\right)$ did not support the hypothesis that they could serve as a sole prey. Feeding upon eukaryote phytoplankton (chlorophytes Monoraphidium minutum, diatoms Cyclotella choc-
\end{abstract}

Address for correspondence: Miroslav Macek, Grupo de Investigación en Limnología Tropical, Universidad Nacional Autónoma de México, 54090 Tlalnepantla, México; E-mail: mirek@unam.mx 
tawhatcheeana) could be of higher importance that previously supposed. Additionally, a use of ingested and retained photosynthetic prokaryotes is hypothesized.

Keywords: Spirostomum teres, ciliate, population dynamics, maar lake, anoxic hypolimnion, picocyanobacteria, feeding rate

\section{INTRODUCTION}

Without any doubt, vertical gradients of dissolved oxygen are behind the changes in both the diversity and abundance of ciliates in stratified water bodies (Fenchel 2012). Their peaks are observed in the metalimnion coupled with the oxycline, or in the water/bottom interface (Bark 1981, Finlay 1981, Berninger et al. 1986, Guhl et al. 1996, Finlay et al. 1996). Along with heterotrophic bacteria as a main feed source for various ciliates, picocyanobacteria can peak there (Modenutti et al. 2002, Callieri 2007, Peštová et al. 2008, BautistaReyes and Macek 2012), depending on a penetration of photosynthetically active radiation (PAR) through the phase boundary and forming picocyanobacteria Deep Chlorophyll Maximum (DCM) (Padisák et al. 2003). However, the abundance of photosynthetic microorganisms is not necessarily reflected in the concentration of dissolved oxygen (DO) there.

Generally, freshwater ciliates found upon anaerobic conditions in less eutrophic water bodies has been scarcely studied except for, e.g., a southern temperate Lake Okaro, New Zealand (James et al. 1995), subtropical lakes Kinneret, Israel (Madoni 1990, Hadas and Berman 1998), Biwa, Japan (Hu and Kusuoka 2015), and tropical monomictic lakes (Yasindi and Taylor 2016, Peštová et al. 2008, Tarbe et al. 2011, BautistaReyes and Macek 2012). All these lakes showed highly important microbial food web processes (as defined in Sarmento 2012) and might include anoxic/anaerobic ciliates as the driving force in their plankton dynamics.

Among the ciliates typical for oxic / anoxic boundary, the genus Spirostomum has been studied for a long time for the huge size up to $3 \mathrm{~mm}$ of their members (e.g., Specht 1934, Foissner et al. 1992). From the point of view of morphology, 8 valid species within the genus are very well defined (revised in Boscaro et al. 2014). However, there are doubts about the molecular identification, e.g., of the smallest species Spirostomum teres isolated from different environments, particularly from the brackish water. Even the interrelationships among $S$. teres populations were not well supported and ap- parently, S. teres was depicted as polyphyletic (Shazib et al. 2016, 2019). Nevertheless, the species is being continuously reported throughout the world (Neidl 1989, Şenler and Yildiz 2004, Jang et al. 2012, Tirjaková et al. 2016).

Ecologically, the genus Spirostomum used to be found in an extreme variety of oxygen concentration (Bick 1958, Foissner et al. 1992) but frequently peaking at the boundary of anoxia. First, the aerobic respiration and the production of ammonium were proven experimentally in the large species S. ambiguum (Specht 1934), having found higher concentration of ammonia upon lower tension of oxygen; the role of food-bacteria in the experiments was speculated. Much later on, $S$. teres respiration rate was evaluated (Laybourn and Finlay 1976) and it was found that it behaved as a typical oxygen conformer (increasing oxygen tension of the medium is reflected in increasing oxygen consumption; Finlay 1977). In addition, the rate was controlled by temperature; $8^{\circ} \mathrm{C}$ already did not support efficient growth (1000 h generation time).

To explain the presence of such respiring ciliate in a limit of the anoxic hypolimnion, two hypothesis has been managed until now: (i) migration of naturally benthic ciliates to the water column due to the oxygen depletion in the very bottom and increasing concentration of reduced compounds such as hydrogen sulphide or ammonium and (ii) ciliate feeding resource-controlled (bottom-up) and predator-prey (top-down) moderated migration, following the oxycline-related organisms (prey) and oxygen-dependent predators (Bark 1981, 1985; Finlay 1981; Laybourn-Parry et al. 1990; Finlay and Esteban 1998, 2009).

Spirostomum teres has been also found in completely anoxic conditions even though, until now, its possible anaerobic respiration is not known. The most common anaerobic respiration is probably that of nitrate that has been proven, e.g., for Loxodes spp. (Finlay 1985) and other protozoa (Hadas et al. 1992). Very recently, a transcriptome of proteins involved in rhodoquinoldependent fumarate reduction to respire in the oxygendepleted habitats were found in a mixotrophic zoochlorella bearing S. semivirescens (Hines et al. 2018).

Curiously, uncomplete data are available on the feeding behaviour of the spirostoma although the first good observation dated one century ago (Bishop 1923). Generally, its efficient filter feeding upon bacteria is supposed (Psenner and Schlott-Idl 1985, Foissner et al. 1992, Adl et al. 2019) but algae and flagellates as a dominant source of feed were also proposed (Bick 
1958, Finlay 1981). S. teres also should ingest photosynthetic sulphur bacteria (Neidl 1989, Foissner et al. 1992). Apart from the abundant data from eutrophic ponds (Bark 1981, Finlay 1981, Madoni 1991, Guhl et al. 1996), other studies were carried out in permanently stratified - meromictic lakes (Psenner and SchlottIdl 1985) and there is a lack of studies from oligotrophic / mesotrophic holomictic lakes with an anoxic hypolimnion.

The use of fluorescently labelled food particles (Sherr and Sherr 1993) is one of the tools how to quantify on a simple way feeding rates of protists. It helped to identify free-living, microphagous plankton protozoa as ubiquitous components of pelagic food webs in freshwater and marine systems. Here they play an important role in the cycling of carbon of the picoplankton and nanoplankton within the microbial loop of the plankton food web and to the metazoans (Azam et al. 1983, Šimek et al. 1995). In the special case of photosynthetic organisms (APP, nanoalgae, photosynthetic anoxygenic bacteria), their autofluorescence facilitated the investigation and applying the dilution method, the feeding budget was proven (e.g., Dolan and Šimek 1997). However, the method has not been used widely with success in the anoxic environment due to the frequently omitted necessity to keep the oxygen concentration as low as possible (Massana and Pedrós-Alió 1994).

The aim of this study was to analyse annual cycle and vertical distribution of the ciliate Spirostomum teres in a warm-monomictic Lake Alchichica (Puebla / Veracruz, Mexico) with a picocyanobacteria-rich metalimnion and an anoxic hypolimnion. Additionally to the actual ciliate monitoring data as a part of long term series, fine ciliate distribution including microstratification below the metalimnion was analysed and feeding experiments with fluorescently labelled picocyanobacteria were performed. Clearance and uptake rates were evaluated along with unpublished data obtained by Peštová (Peštová et al. 2008) and Bautista-Reyes (Bautista-Reyes and Macek 2012). The lake Alchichica results were compared with those from a neighbour Lake La Preciosa (Puebla, Mexico) and the meromictic karstic lake Laguna de la Cruz (La Cuenca, Leon y Castilla, Spain).

\section{MATERIALS AND METHODS}

\section{Study area}

Long-term study has been carried out regularly on a month basis in a maar-crater Lake Alchichica (Puebla / Veracruz, México; $19^{\circ} 24^{\prime} \mathrm{N}, 97^{\circ} 24^{\prime} \mathrm{W}, 2,340 \mathrm{~m}$ above sea level). The climate is dry and temperate with a mean annual temperature of $12.9^{\circ} \mathrm{C}$ and mean annual precipitation of less than $400 \mathrm{~mm}$ concentrated in the (summer) rainy season. The lake is warm-monomictic, $62 \mathrm{~m}$ deep (mean depth $40.9 \mathrm{~m}$ ) with a surface area of $2.3 \mathrm{~km}^{2}$ (Filonov et al. 2006), athalassohaline (8.5 $\mathrm{g} \mathrm{L}^{-1}$ ) and alkaline ( $\left.\mathrm{pH} 8.9\right)$ (Armienta et al. 2008). It is a low-productive lake with an average annual chlorophyll $a$ concentration below $4 \mu \mathrm{g} \mathrm{L}^{-1}$ (Macek et al. 2009).

The neighbouring Lake La Preciosa $\left(19^{\circ} 22^{\prime} \mathrm{N}, 97^{\circ} 23^{\prime} \mathrm{W}\right)$ is also a maar-crater produced by three phreatomagmatic explosions, $45 \mathrm{~m}$ deep with monomictic regimen. It has alkaline freshwater (1.1 $\mathrm{g} \mathrm{L}^{-1}$ salinity) with $\mathrm{pH}$ of 8.6 (Armienta et al. 2008).

Laguna de la Cruz (Lake La Cruz) is a small karstic meromictic lake located in Central-Eastern Spain, rich in bicarbonates, calcium and magnesium, with high $\mathrm{pH}$ values of $>8.3$, and very poor in sulphate and chloride. The lake monimolimnion has similar chemical components, but concentrations are higher, especially that of calcium and iron (for more details, see, Camacho et al. 2017).

\section{Sampling}

Alchichica and La Preciosa samples were taken from the deepest part of the lake, choosing the depths according to measured profiles of temperature, dissolved oxygen, DO (Hydrolab DS4/ SVR4 Water Quality Monitoring System; a Clark cell electrode, from 2015 luminescent dissolved oxygen sensor), natural chlorophyll $a$ fluorescence and photosynthetically active radiation, PAR (Biospherical PFN-300 profiler; Biospherical Instruments). Until 2012, fluorescence data did not cover the dark layers but then, apparent fluorescence of chlorophyll $a$, phycoerythrin and phycocyanin was analysed in in situ using a WETlab ECO-Triplet (USA) underwater fluorimeter.

$S$. teres samples from Alchichica included to the study came from the monthly monitoring at 5 chosen layers from June 2003 to May 2005, then $>8$ (mixing) and $>10$ layers (stratification) were routinely analysed till March 2009 (Peštová et al. 2008, BautistaReyes and Macek 2012). Detailed metalimnion / anoxic hypolimnion studies were performed from 2011 to November 2014 (see, Sánchez-Medina et al. 2016) and since the second half of 2015 to December 2016. La Preciosa samples were analysed from three September-October samplings during 2011, 2012 and 2016.

La Cruz was sampled in a single campaign (June 2010) and the samples were taken in the deepest point of the lake using a peristaltic-pump sampler (Jørgensen et al. 1979) in the layer distance of $25 \mathrm{~cm}$.

\section{Procedures}

Picoplankton were analysed in the samples fixed with formalin to $2 \%$ (Straškrabová et al. 1999), cropped on polycarbonate membranes $(0.2 \mu \mathrm{m}$ pore-sized; Osmonics, Germany). Direct numbers of heterotrophic picoplankton, HPP (bacterioplankton) were evaluated on DAPI-stained black membranes (Porter and Feig 1980), mounted in immersion oil and observed in epifluorescence microscope (Leica 
DMLB, Germany); One to $3 \mathrm{~mL}$ were cropped onto $1 \mathrm{~cm}$ diameter membrane. Autotrophic picoplankton, APP were evaluated on white $0.2 \mu \mathrm{m}$ membranes mounted in immersion oil via phycobilins' autofluorescence using an Y3 filter set comparing with chlorophyll I3 set (Leica, Germany); four to $20 \mathrm{~mL}$ were cropped onto $1 \mathrm{~cm}$ diameter membrane.

Since 2009, photosynthetic bacteria possessing bacteriochlorophylls were analysed in the samples harvested on black $1 \mu \mathrm{m}$ polycarbonate membranes through their infrared fluorescence. The images were taken with IR-sensitive camera (Hitachi, Japan) using the same filter sets (I3 and Y3) to exclude cyanobacteria and eukaryotic chlorophyll possessing cells.

To count ciliates, two methods were used in parallel: epifluorescence DAPI staining and quantitative protargol stain (QPS). The samples for epifluorescence were fixed as recommended by Sherr and Sherr (1993) with Lugol's iodine, immediately decolourized with thiosulphate and postfixed with formalin. Ciliates were observed on DAPI stained black $2 \mu \mathrm{m}$ polycarbonate membranes (Osmonics, Germany); twenty to $60 \mathrm{~mL}$ were cropped onto $1 \mathrm{~cm}$ diameter membrane and repetitions were carried out according to the abundance.

For QPS (method modified following Montagnes and Lynn 1993 and Skibbe 1994 recommendations), the samples were directly fixed or post-fixed with Bouin's fixative to 7\% v/v (Montagnes and Lynn 1993) and stabilised against precipitation using saturated solution of Seignette's salt (Sodium Potassium - Tartrate) to $0.4 \%$. Ciliates were cropped and agar-mounted onto cellulose esters' membrane filters (1.2 $\mu \mathrm{m}$, Millipore, Ireland), and the agar was formalin fixed, stained, dehydrated (ethanol 70\%,96\%, 96\%, phenol-xylene 2:3, xylene) and neutral Canada balsam-mounted. Depending both on the phytoplankton and ciliate abundance, twenty to $50 \mathrm{~mL}$ was concentrated; impregnation was repeated according to the cell counts. The whole filter area was inspected using $20 \times$ objective. For identification (Foissner et al. 1992, Boscaro et al. 2014 and the literature cited therein), $40 \times$ and $100 \times$ APO oil immersion objective (Leica DMLB; Germany) equipped with Nomarski (DIC) were used.

To evaluate the grazing rates of ciliates, fluorescently labelled APP (FLB) were prepared from cultured picocyanobacteria Synechococcus sp., harvested by centrifugation. APP were fluorescently labelled according to the protocol of Sherr and Sherr (1993), replacing phosphate buffer saline with the filtered Alchichica water (pH 8.9).

For the grazing experiments, incubation flasks (black BOD bottles) were tube-filled directly from the sampler equipped with $100 \mu \mathrm{m}$ screen and 2 to 3 volumes were permitted to wash-out. The tracer addition was estimated to constitute $10 \%$ of the natural APP abundances and the incubation was stated to 20 and $40 \mathrm{~min}$. Even though the unexpected fluctuations in in situ APP caused a variation of the percentage of the tracer, the addition never exceeded $20 \%$ of total picoplankton numbers. The incubations were finished adding $0.5 \mathrm{v} / \mathrm{v}$ of acid Lugol's solution, followed by clearing with sodium thiosulphate solution and post-fixed by formalin to $2 \%$ (Sherr and Sherr 1993). The ciliate (volume) clearance rate was calculated according to Fenchel (1986). Linearity of the increase of ingestion by $S$. teres within the $20 \mathrm{~min}$ and $40 \mathrm{~min}$ was verified, passing roughly through the origin.

The Lake La Cruz feeding experiments were performed in the laboratory using the Helium-bubbled samples (avoiding oxygen inhibition of the feeding activity) and adding FLB prepared from heterotrophic bacteria resembling the lake picocyanobacteria size and form, labelled as explained above.

\section{Chemical analysis}

Samples for nutrient analysis were on-boat positive pressure filtered through $0.2 \mu \mathrm{m}$ pore cellulose acetate syringe filters Millex (Millipore), collected in polypropylene containers and stored frozen until analysis. Analyses of ammonium $\left(\mathrm{NH}_{3}\right)$, nitrite $\left(\mathrm{N}_{-} \mathrm{NO}_{2}^{-}\right)$and nitrate nitrogen $\left(\mathrm{N}-\mathrm{NO}_{3}^{-}\right)$, dissolved reactive phosphorus (DRP) and silicon $\left(\mathrm{SiO}_{2}\right)$ were performed using a segmented flow autoanalyzer (Skalar San-plus System) following the standard methods adapted by Hansen and Koroleff (1999). Data on nutrients in the ciliate fine stratification sampling points, which have not been analysed, were estimated via depth-weighted lineal interpolation within the water column (regularly, ten representative depths were sampled).

\section{Multivariate ordination analyses}

For the Lake Alchichica samples, which covered the majority of Spirostomum teres dataset, a distance-based redundancy analysis (dbRDA) ordination analysis was performed in order to link the abundance and distribution of $S$. teres, APP and HPP within the environmentally constrained space; the R package vegan (Borcard et al. 2018) was employed. An environmental matrix including 7 environmental variables was analysed: dissolved oxygen (DO), ammonium $\left(\mathrm{NH}_{3}\right)$, nitrite $\left(\mathrm{NO}_{2}^{-}\right)$, nitrate $\left(\mathrm{NO}_{3}^{-}\right)$, dissolved reactive phosphorus (DRP) and silicon $\left(\mathrm{SiO}_{2}\right)$. The variables were normalized (each variable have their mean subtracted and are divided by their standard deviation) and the resemblance matrix was calculated based on the Euclidean distance. The abundance matrix built-up with the abundance data of $S$. teres, APP and HPP were square root transformed and standardized, and the resemblance matrix was performed based on the Bray-Curtis dissimilarity (Borcard et al. 2018). The ordination analysis of the selected samples in relation to environmental variables and abundances of $S$. teres, APP and HPP was plotted for the two main axes of the dbRDA analysis.

\section{RESULTS}

\section{Lake stratification}

Lake Alchichica presented typical monomictic pattern that has not changed during the study. However, the water circulation temperature was apparently increasing from about $14.4^{\circ} \mathrm{C}$ at the beginning to $15.3^{\circ} \mathrm{C}$ at the end of the study (Fig. 1). Well defined epilimnion and the maximum differences between the surface and bottom temperatures of $>5^{\circ} \mathrm{C}$ were observed from May to November. The width of metalimnion was the highest between July and September while it shrank during the late stratification since October, presenting the most pronounced gradient of temperature (even over $1^{\circ} \mathrm{C} \mathrm{m}^{-1}$ ).

Surface of the mixed layer presented dissolved oxygen concentration (DO) around the saturation (approx. $6.6 \mathrm{mg} \mathrm{L}^{-1}$ ) but during the early mixing, when the low- 
est DO were found (below $5 \mathrm{mg} \mathrm{L}^{-1}$ throughout the water column). According to the water temperature the circulation was possible from December or early January through March but occasionally, the water column was not mixed or it was mixed partially even during January (years 2010, 2013 and 2016) and zero dissolved oxygen concentration layer remained below 45 or $50 \mathrm{~m}$. With some exceptions, the whole hypolimnion was observed anoxic since May.

Very similar photosynthetically active radiation (PAR) pattern was observed inter-annually. The one percent PAR layer (euphotic zone) ranged between 15 and $20 \mathrm{~m}$ during the mixing and dropped down below $30 \mathrm{~m}$ at the end of the stratification period, coinciding with the metalimnetic bottom (Fig. 1b). However, $0.1 \%$ PAR which could define the layer hosting photosynthetic anoxygenic bacteria, used to be found during the stratification below $25 \mathrm{~m}$, lowering to 35 or even $40 \mathrm{~m}$ just before mixing. Deep chlorophyll maximum (DCM) composed mainly by diatoms (Cyclotella alchichicana) was observed following the stabilization of the lake stratification.

\section{Prokaryote dynamics}

The dynamics of prokaryotic plankton in Lake Alchichica followed a periodical warm-monomictic pattern, linked to the hydrodynamics of the lake (i.e., stratification and circulation periods).

Maximums of autotrophic picoplankton (APP), almost only picocyanobacteria, were observed during the mixing period (the maximum depth weighted column mean from $3.4 \times 10^{5}$ in 2012 to $9.4 \times 10^{5}$ cells $\mathrm{mL}^{-1}$ in 2007; median of maximums being $5.8 \times 10^{5}$ cells $\mathrm{mL}^{-1}$ ) peaking almost all years during March (annual changes of mean data pooled in the Figure 2; all data used in the Figs. 14 and 15). However, preceding local peaks of APP were observed two month before just during the first mixing event (December) or during February, if the APP maximums were reached between April and May.

Maximum numbers of HPP (heterotrophic picoplankton) were observed also during the mixing period, generally along with the maximum APP, from the end of February through March (the maximum column mean $2.5 \times 10^{6}$ to $1 \times 10^{7}$ cells $\mathrm{mL}^{-1}$; median of maximums $4.2 \times 10^{6}$ cells $\mathrm{mL}^{-1}$ ), exceptionally during April or May along with the second (higher) peak of APP. During the stratification when the Spirostomum teres development was being found, HPP means laid between $8 \times 10^{5}$ and $2.5 \times 10^{6}$ cells $\mathrm{mL}^{-1}$.
Even though the annual pattern was very similar for APP and HPP, big differences were found in their stratification. During mixing, HPP were found homogeneously distributed while during the stratification, the peak close to the metalimnion limit but without well pronounced pattern was found (see, Fig. 3; all HPP used to characterize the $S$. teres habitat in Fig. 14). On the other hand, APP were found stratified almost throughout the year. During mixing, numbers were maximum in the euphotic layer $>1 \%$ of PAR (until 2013, 1 to $3 \times 10^{6}$ cells $\mathrm{mL}^{-1}$ ) dropping along with PAR attenuation, in particular, below $0.1 \%$; in 2016 , the maximum of $7 \times 10^{5}$ cells $\mathrm{mL}^{-1}$ was found. During stratification, the epilimnetic APP did not mostly surpass $2 \times 10^{5}$ cells $\mathrm{mL}^{-1}$ while higher numbers (up to $1 \times 10^{6}$ cells $\mathrm{mL}^{-1}$ ) were found peaking below the thermocline / oxycline. However, according to the phycobilins and chlorophyll $a$ fluorescence, APP were observed in good condition and important numbers minimum $4 \mathrm{~m}$ below the DO disappearance. APP were also found near the bottom exceeding $10^{4}$ cells $\mathrm{mL}^{-1}$ during the mixing and $10^{3}$ cells $\mathrm{mL}^{-1}$ during the stratification.

Large bacteriochlorophyll possessing purple sulphur-like bacteria were observed in Alchichica, generally, from July or August until December/January in the layers just below the oxygen limit, reaching numbers even $>1 \times 10^{4}$ cells $\mathrm{mL}^{-1}$ (annual development is not shown). Additionally to IR images, bacterial elemental sulphur deposits were proven in the QPS preparations as silver sulphide precipitate. The meromictic Lake La Cruz (Cuenca, Spain) possess much higher numbers of such bacteria during the whole year (Camacho et al. 2017). On the other hand, in the Lake La Preciosa we observed minute photosynthetic bacteria forming chains also just below the oxygen limit.

\section{Spirostomum teres}

The ciliate sampling dates and layers, and $S$. teres numbers are pooled in the Figure (Fig. 3) along with the hypoxic layer $\left(\mathrm{DO}<1 \mathrm{mg} \mathrm{L}^{-1}\right)$ average numbers of the ciliate. $S$. teres was found first in the near bottom / $60 \mathrm{~m}$ samples and in the oxycline from May through September/November since the launch of ciliate monitoring in Alchichica in 2003; the first years' sampling was limited to five to 10 layers, i.e., the register would not be complete $(S$. teres was misidentified in Peštová et al. 2008 and Bautista-Reyes and Macek 2012 as Chaetospira sp.). Typically, S. teres was colonizing the oxycline just after the stratification (May) but still it has been found in the very bottom layer until 2009 (the end of the first monitoring period). Maximum numbers 
Depth [m]
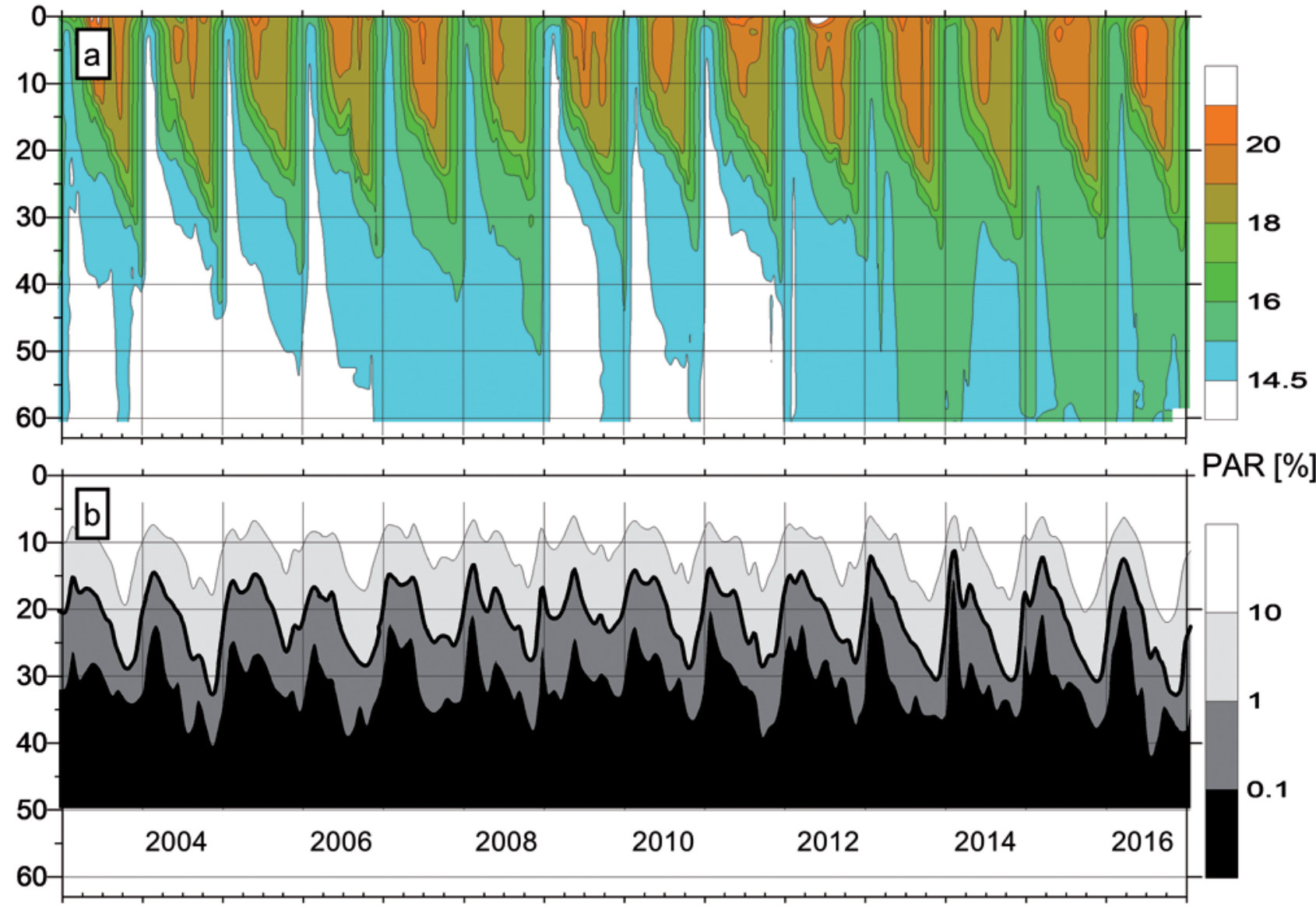

Fig. 1. a) Temperature and b) photosynthetically active radiation profiles in Lake Alchichica.

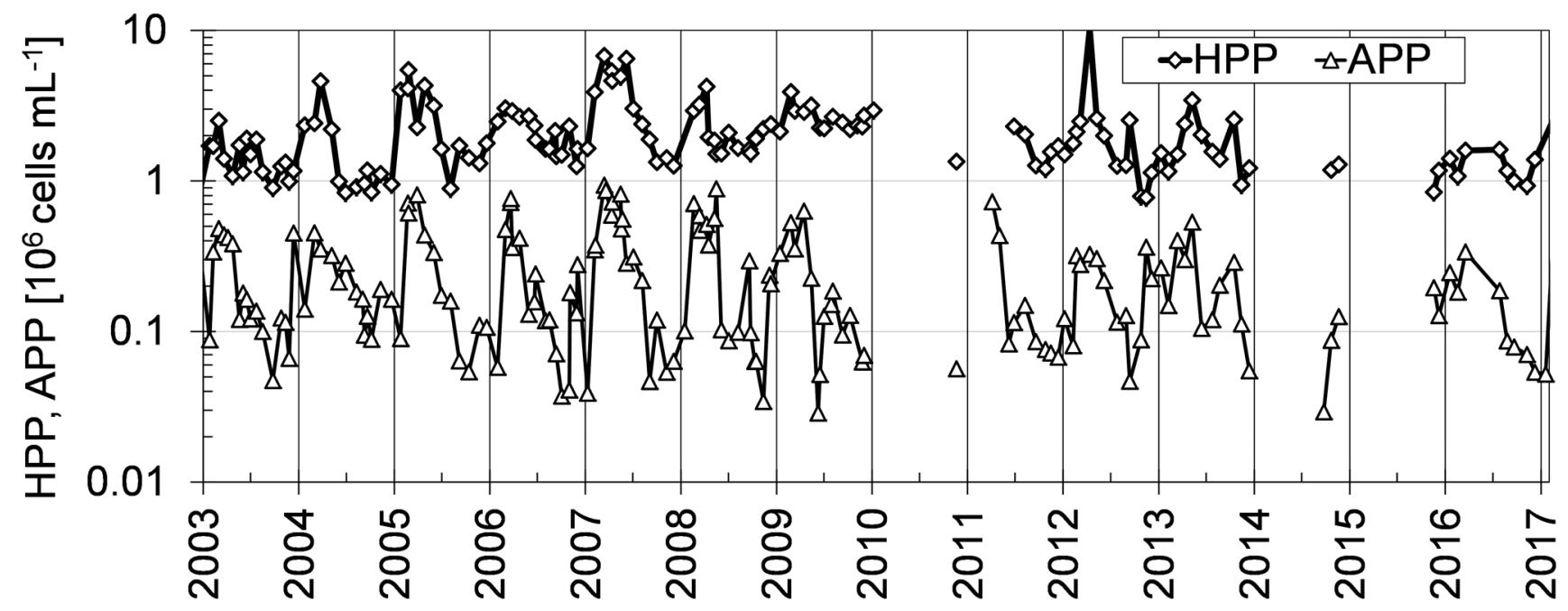

Fig. 2. Heterotrophic (HPP) and autotrophic picoplankton (APP) in Lake Alchichica (based on Peštová et al. 2008, Macek et al. 2009, Hernández-Avilés et al. 2010, Bautista-Reyes and Macek 2012, Sánchez-Medina et al. 2016, Pájares et al. 2017, and this study). 


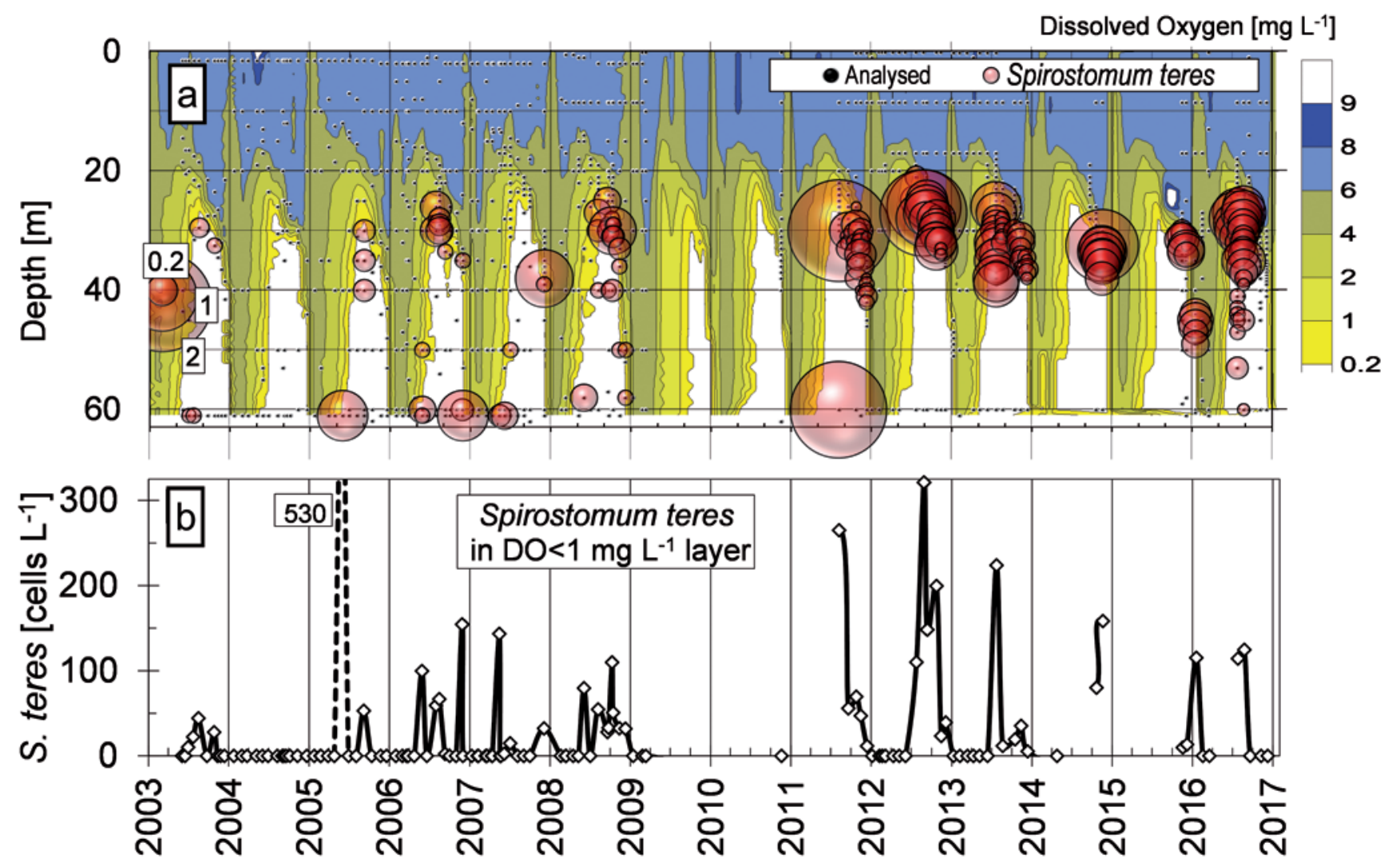

Fig. 3. a) Dissolved Oxygen isopleths, sampled data/depths (Analysed), and of Spirostomum teres numbers in Lake Alchichica; b) average S. teres numbers throughout an hypoxic/anoxic layer (based on Peštová et al. 2008, Bautista-Reyes and Macek 2012, Sánchez-Medina et al. 2016, and this study).

of 700 cells $\mathrm{L}^{-1}$ were found within the sampled layers, while the average number integrated through the whole hypolimnion $\left(\mathrm{OD}<1 \mathrm{mgL}^{-1}\right.$ ) was found regularly up to 150 cells L $\mathrm{L}^{-1}$; a high number of 530 cells $\mathrm{L}^{-1}$ was found when the anoxic layer was limited to the very bottom layer on May 2005.

Since 2011 when the sampling already included over 10 layers within- and below-oxycline (bubbles in the Fig. 3), S. teres has gradually disappeared from the bottom and it was found in quite restricted layer below the oxycline. However, still in August 2011 the maximum bottom abundance of $S$. teres $\left(1900\right.$ cells $\left.\mathrm{L}^{-1}\right)$ was observed. The samples were not taken during the whole stratification period but it seems the pelagic population of $S$. teres was decreasing. Frequently, annual maximums of 1000 to 2100 cells $\mathrm{L}^{-1}$ were found during the stable stratification with the light penetrating the microaerobic layer (July-August of 2011, 2012, 2013, 2016). On the other hand, $S$. teres has not been found during the finishing stratification that was not already supported by strong temperature gradient while oxygen stratification persisted; in 2016, the last samplings within the study, $S$. teres was absent already from November. Additionally, January peak (265 cells $\mathrm{L}^{-1}$ ) was found around $45 \mathrm{~m}$ during the uncomplete mixing in 2016.

Examples of the whole limnologic variables, which accompanied the typical $S$. teres vertical distribution are pooled in the Fig. 4. In Alchichica, the ciliate distribution was extended through the metalimnion during July-August (Fig. 4 a-h). There was no evident exceeding maximum but $S$. teres was observed in much wider metalimnion-hypolimnion boundary layers, following cyanobacterial pigments distribution, below the chlorophyll $a$, phycoerythrin and phycocyanin maximums. Still, apparent photosynthetic anoxygenic bacteria (PAB) were not so important there. Maximum abundances were found located 2 to $4 \mathrm{~m}$ below the limit of DO. Also nitrates were sometimes peaking there. 


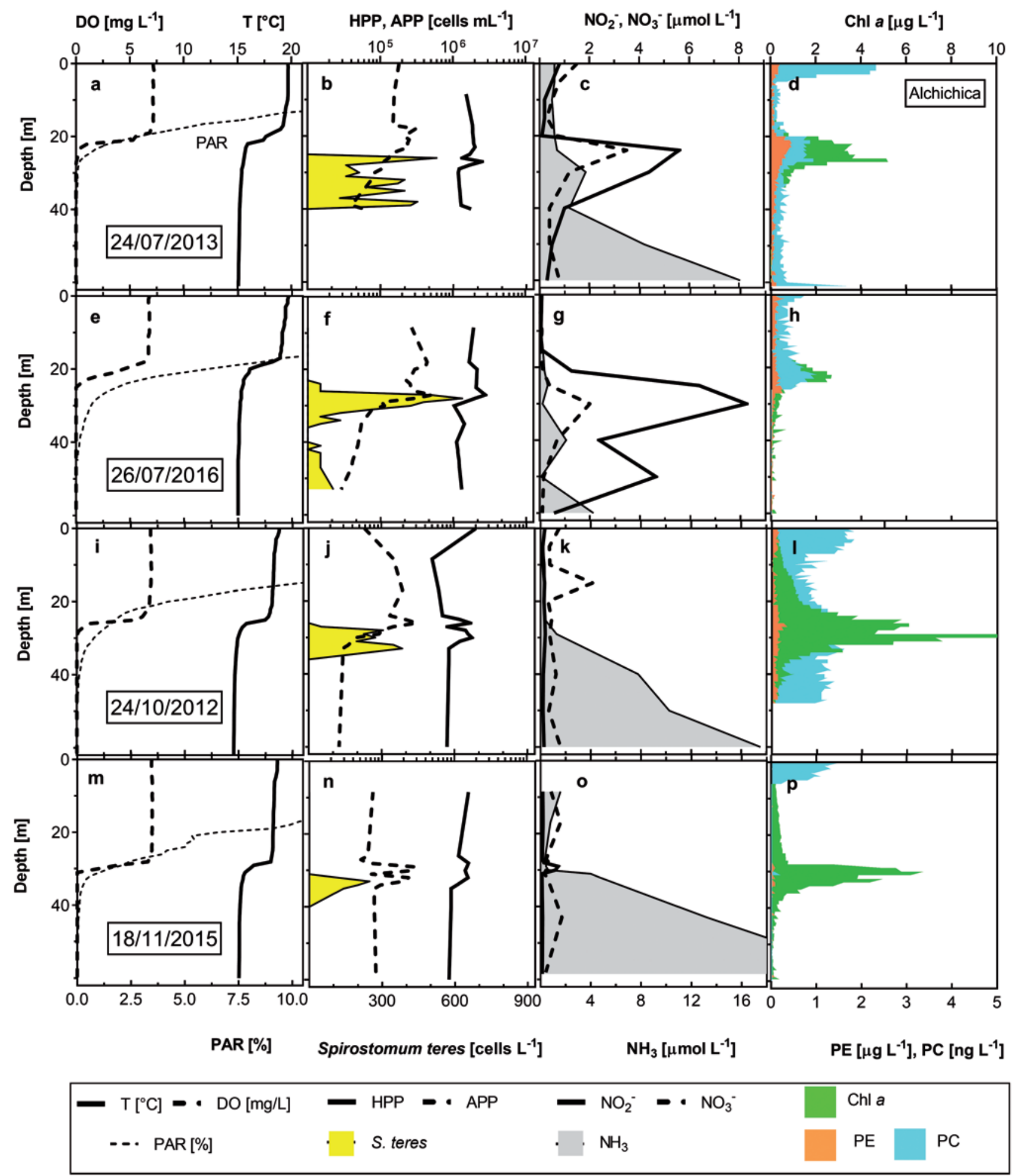

Fig. 4. Representative early- (a to $\mathbf{h})$ and late-stratification (i to $\mathbf{p}$ ) of Spirostomum teres in Lake Alchichica. a, e, i, $\mathbf{m}$ ) Temperature, $\mathbf{T}\left[{ }^{\circ} \mathbf{C}\right]$, Dissolved oxygen, DO [ $\mathbf{m g ~ L}^{-1}$ ], and Photosynthetically active radiation PAR [\%]; $\mathbf{b}, \mathbf{f}, \mathbf{j}, \mathbf{n}$ ) numbers of heterotrophic-, HPP [cells $\mathbf{m L} \mathbf{L}^{-1}$ ] and autotrophic picoplankton, APP [cells $\mathbf{~ m L}^{-1}$ ], and Spirostomum teres [cells $\mathbf{L}^{-1}$ ]; $\mathbf{c}, \mathbf{g}, \mathbf{k ,}, \mathbf{o}$ ) nitrites, $\mathbf{N O}_{2}^{-}$, nitrates $\mathbf{N O}_{3}^{-}$and ammonium, $\left.\mathbf{N H}_{3}\left[\mu \mathrm{mol} \mathrm{L}^{-1}\right] ; \mathbf{d}, \mathbf{h}, \mathbf{l}, \mathbf{p}\right)$ chlorophyll $a, \mathbf{C h l} \boldsymbol{a}\left[\boldsymbol{\mu g} \mathbf{L}^{-1}\right]$, phycoerythrin, $\mathbf{P E}\left[\boldsymbol{\mu g} \mathbf{L}^{-1}\right]$, and phycocyanin, $\mathbf{P C}\left[\mathbf{n g ~ L}^{-1}\right]$. 


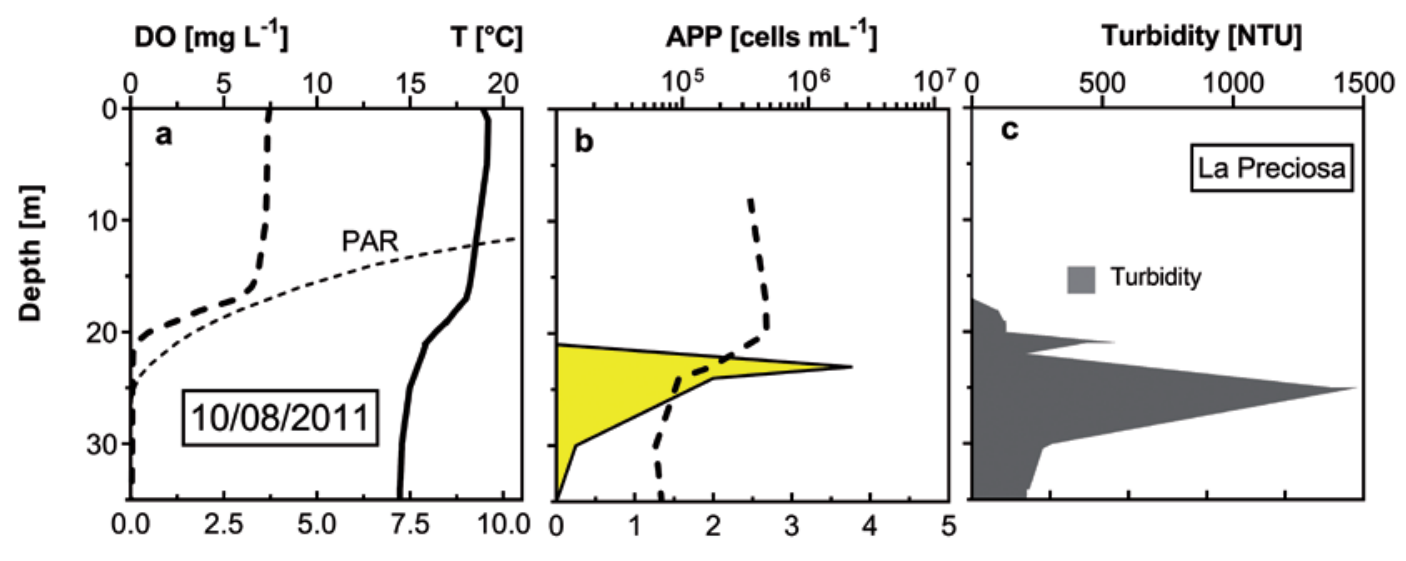

PAR [\%] Spirostomum teres [cells $\mathrm{L}^{-1}$ ]

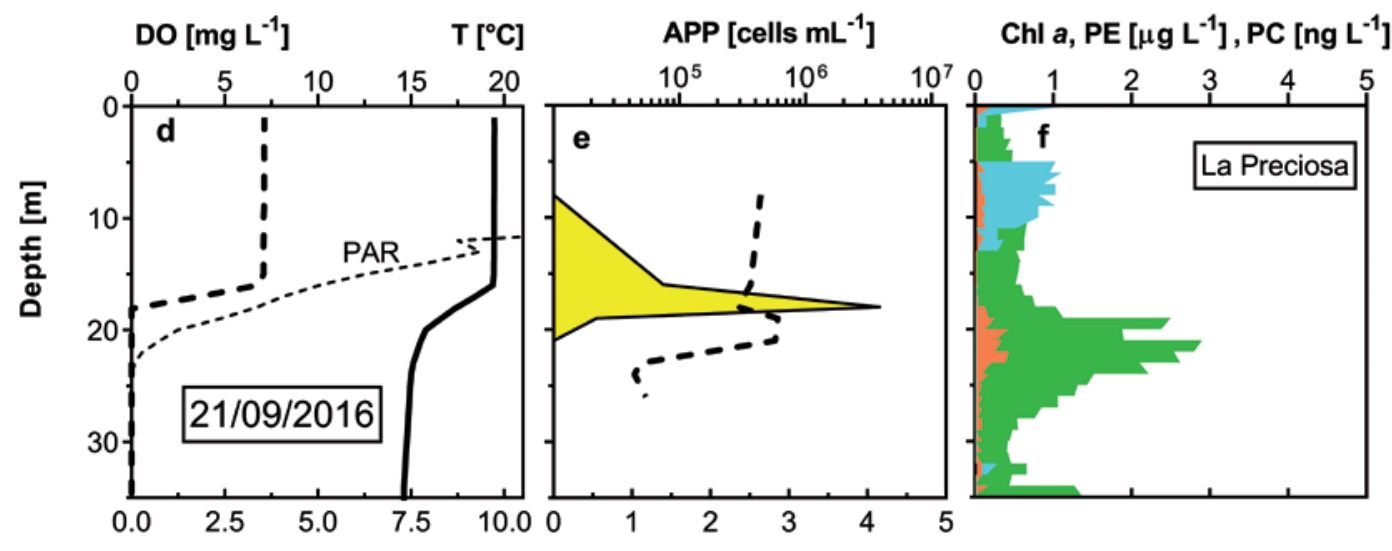

PAR [\%] Spirostomum teres [cells L ${ }^{-1}$ ]

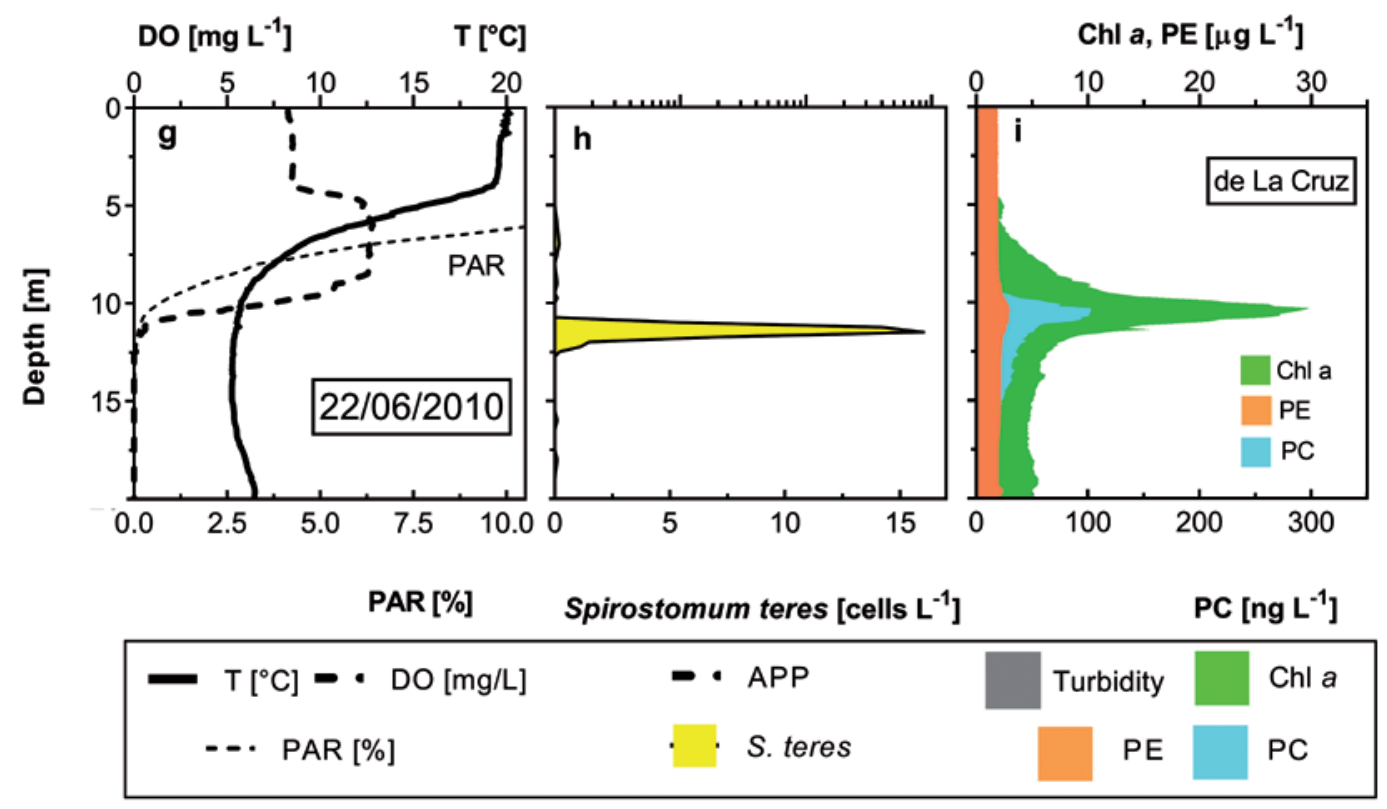

Fig. 5. Representative Spirostomum teres sampling profiles in Lake La Preciosa (a to c) and Lake de La Cruz (d to f). a, d, g) T [ $\left.{ }^{\circ} \mathbf{C}\right]$, Dissolved oxygen, DO [mg L $\mathbf{~}^{-1}$, and Photosynthetically active radiation PAR [\%]; b, e, h) numbers of APP [cells $\mathbf{m L}^{-1}$ ] (not analysed in de La Cruz) and of Spirostomum teres [cells $\mathbf{L}^{-1}$ ]; c) turbidity [NTU]; f, I) chlorophyll $a$, Chl $a$ [ $\mu \mathbf{g ~ L}^{-1}$ ], phycoerythrin, $\mathbf{P E}\left[\mu \mathrm{g} \mathbf{L}^{-1}\right.$ ] , and phycocyanin, PC [ng $\mathbf{L}^{-1}$ ]. 
Contrasting situation was found at the end of the stratification period, when higher ciliate numbers were observed in a strictly limited oxygen boundary (Figs. 3, 4), accompanied by above mentioned bacteria. Nitrite peak was not as high as in July but, percentually, it was important (Fig. 4 c, g, k, o).

Very similar $S$. teres distribution pattern was found in nearby lake La Preciosa (Fig. 5 a-f). S. teres was found in higher numbers in similar DO conditions but below the phycocyanin maximum (composed by picocyanobacteria colonies and/or aggregates) and just above the maximum of chlorophyll $a$.

A meromictic Lake La Cruz (Spain) showed similar $S$. teres distribution pattern even though on a $1 / 4 \mathrm{~m}$ distance basis (Fig. $5 \mathrm{~d}$ to $\mathrm{f}$ ). The ciliate was found peaking in a very narrow layer just within the maximum of pigments, in a limit of DO.

According to QPS preparations, the ciliates from the three lakes were morphologically very similar even though, different composition of water did not permit to obtain all cells equal impregnated (Fig. 6).

\section{Spirostomum teres feeding}

During the study, the samples inspected in vivo did not present any colour that could be related directly to their food (the ciliate was yellowish to brown due to its pigment granules). Vacuole content was analysed in all S. teres samples using its fluorescence \& DAPI staining both in the quantitative ciliate samples fixed primarily with Lugol and in the samples fixed with formalin, in which fluorescence of picocyanobacteria and chlorophyll bearing eukaryotes persisted longer - up to one week; FLB were very well distinguishable in both treatments. However, to observe DAPI stained heterotrophic bacteria inside the vacuoles was almost impossible for the samples fixed with Lugol but according to the size of a vacuole and the content of APP we were able to estimate their relative content (Fig. 7).

Samples from all three lakes showed abundant APP inside the vacuoles along with algae (Fig. 8). Alchichica samples presented relative lower amount of then but still, they were observed throughout the season in all layers, including the very bottom. In Alchichica, within the larger feeding particles, apparent purple sulphur bacteria (Thiocapsa-like; genus to be confirmed) were observed in protargol impregnated samples and in IRtaken autofluorescence images (Fig. 9), typically at the end of stratification (October-November). However, throughout the study, sulphur bacteria did not form the dominant content of food vacuoles.
Sulphur bacteria were not found abundant inside the cells neither in La Preciosa or La Cruz samples, even though they were very abundant in the latter lake. Other apparently photosynthetic anoxygenic bacteria from $\mathrm{La}$ Preciosa (numbers not shown) were not observed ever to be ingested.

Other photosynthetic organisms like green algae or diatoms were found frequently although, with some exception, forming only a part of the cell content. Alga Monoraphidium minutum, which was observed frequently throughout the water column even during stratification (including hypoxic/anoxic hypolimnion), was the most important ingested eukaryote but only in the July 2016, several specimens hosted dominantly the alga (Fig. 7c). Other typical food was a minute diatom Cyclotella choctawhatcheeana, sometimes found in Alchichica $S$. teres while very numerous in La Cruz sampling and experiment (Fig. 6c). No important eukaryotes were found in the $S$. teres population of La Preciosa.

Feeding rate experiments (pooled in the Table 1; Fig. 10) were evaluated during late stratification of the crater lakes giving similar results for the samples with abundant ciliates. Typical Alchichica clearance rate laid about $2000 \mathrm{~nL} \mathrm{cell}{ }^{-1} \mathrm{~h}^{-1}$, which represented in average 130 to 210 cells cell ${ }^{-1} \mathrm{~h}^{-1}$ ingested. La Preciosa population showed roughly similar clearances but the grazing rates were much more variable in different layers reaching sampling averages 46 to 488 cells cell ${ }^{-1} \mathrm{~h}^{-1}$ ingested.

Field measurement of Lake La Cruz S. teres population did not give positive results due to the logistic problems. However, the experiment with the whole community transported to the laboratory had success. The clearance rates were observed being much lower than those from Mexican lakes; on the other hand, grazing was similar to Alchichica data.

\section{Ecological relationships}

With some exceptions, the oxycline and hypolimnion layers, where $S$. teres was found, showed oxygen concentration below $1 \mathrm{mg} \mathrm{L}^{-1}$ with maximum over 2000 cells $\mathrm{L}^{-1}$ at DO of $0.2 \mathrm{mgL}^{-1}$ and lower (Fig. 11). Notoriously, $S$. teres was found at DO below the accuracy limit within the completely anoxic hypolimnion. The ciliates were observed regularly at the very bottom including in anaerobic conditions until 2011, when large number of 1900 cells L ${ }^{-1}$ was found. S. teres appeared there again in 2016 (Fig. 3).

To see a possible anaerobic respiration within the sampled layers, $S$. teres numbers were plot against DO and a nitrate concentration (Fig. 12). S. teres maximums were found upon concentrations over $1 \mu \mathrm{mol} \mathrm{L}-1$ 


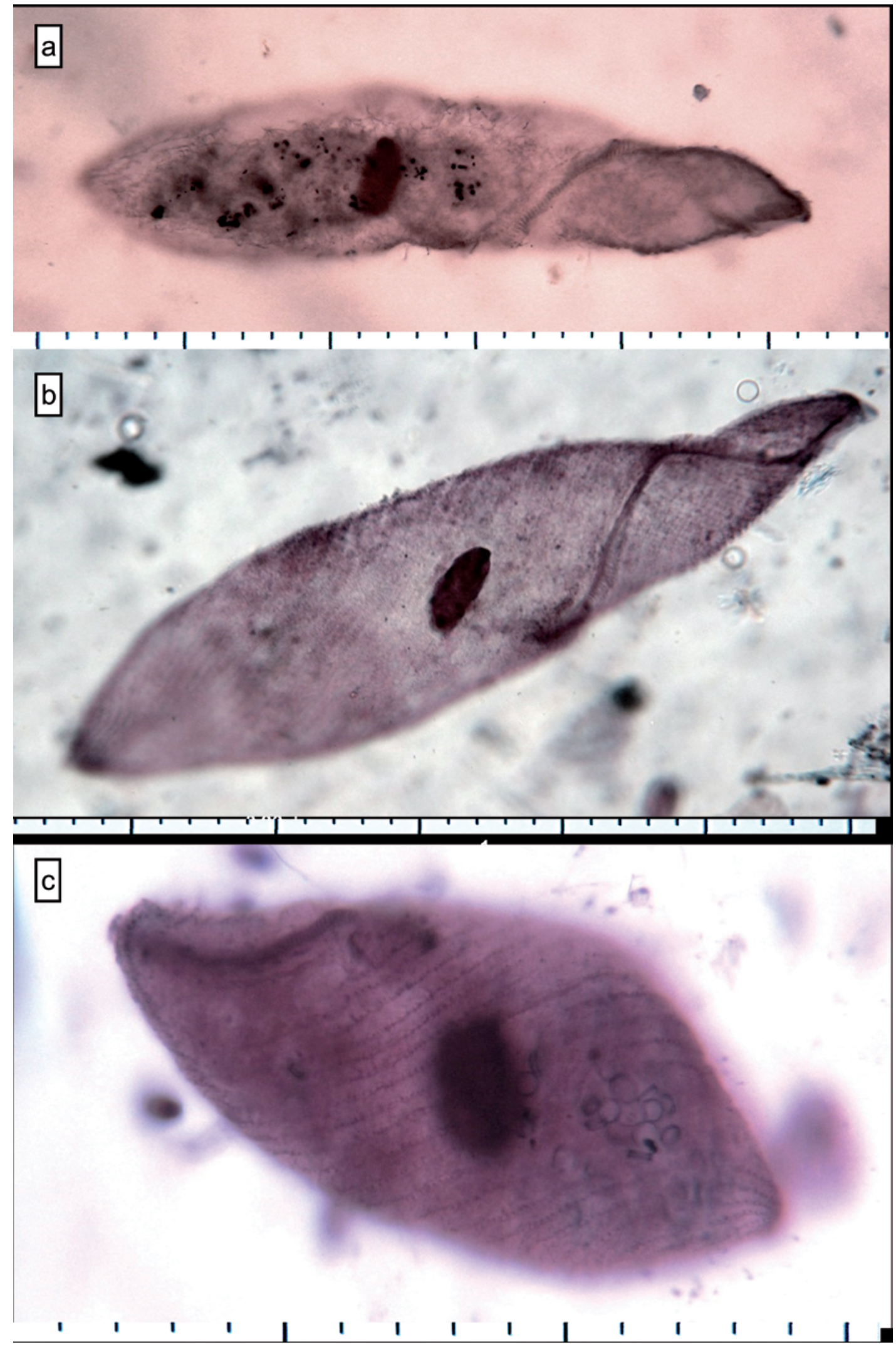

Fig. 6. Spirostomum teres: a) Lake Alchichica (8/8/2011, 30 m), b) Lake La Preciosa (2/9/2011, 20.5 m and c) Lake de La Cruz (25/6/2010, $11.25 \mathrm{~m}$. Protargol stain (QPS). $1 \equiv 10 \mu \mathrm{m}$. 


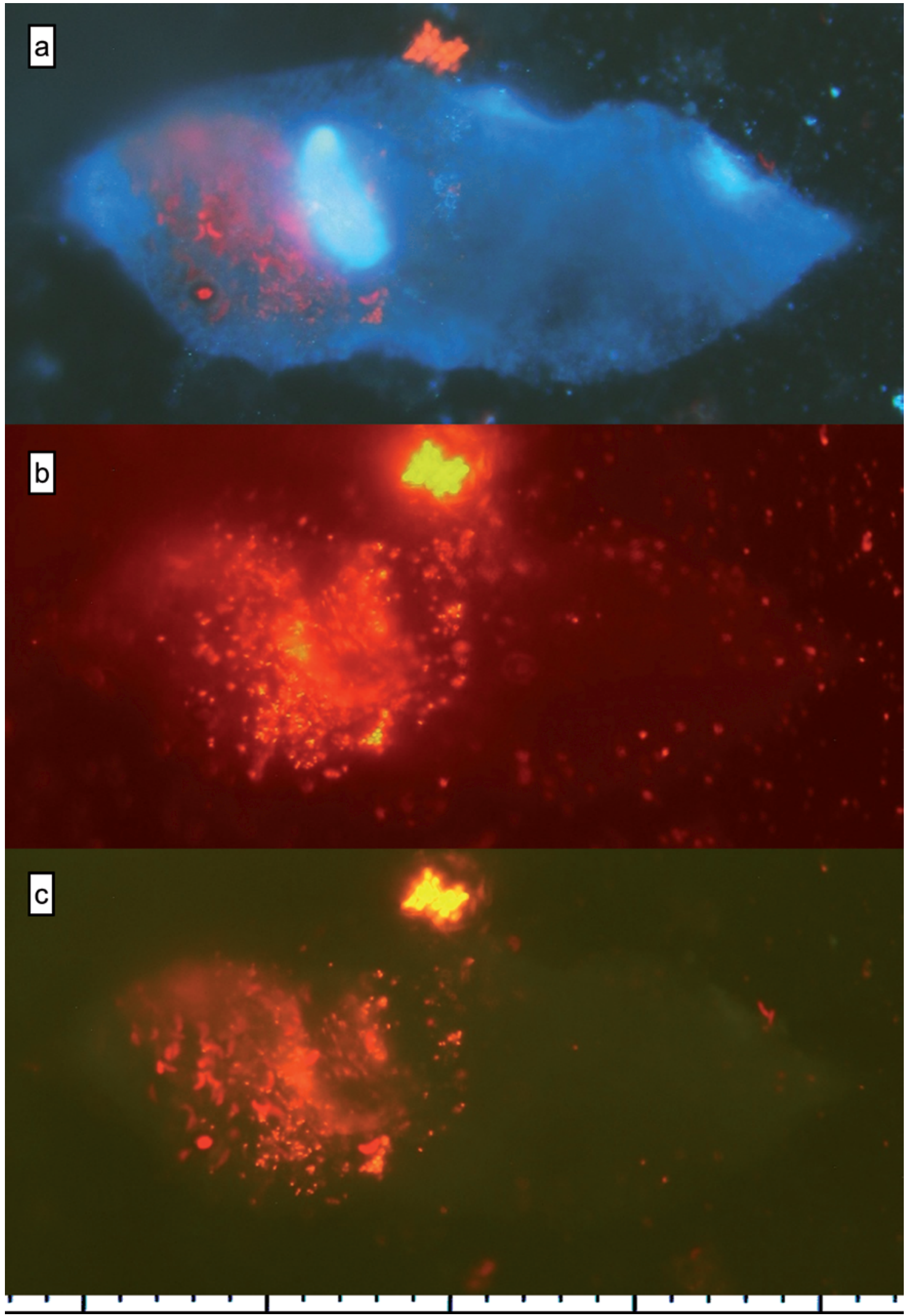

Fig. 7. Spirostomum teres in Alchichica on July 2016 (epifluorescence microscope, Leica DMLB). a) DAPI staining; b) Phycobilin filter set (Y3); c) Chlorophyll $a$ filter set (I3). $1 \equiv 10 \mu \mathrm{m}$. 


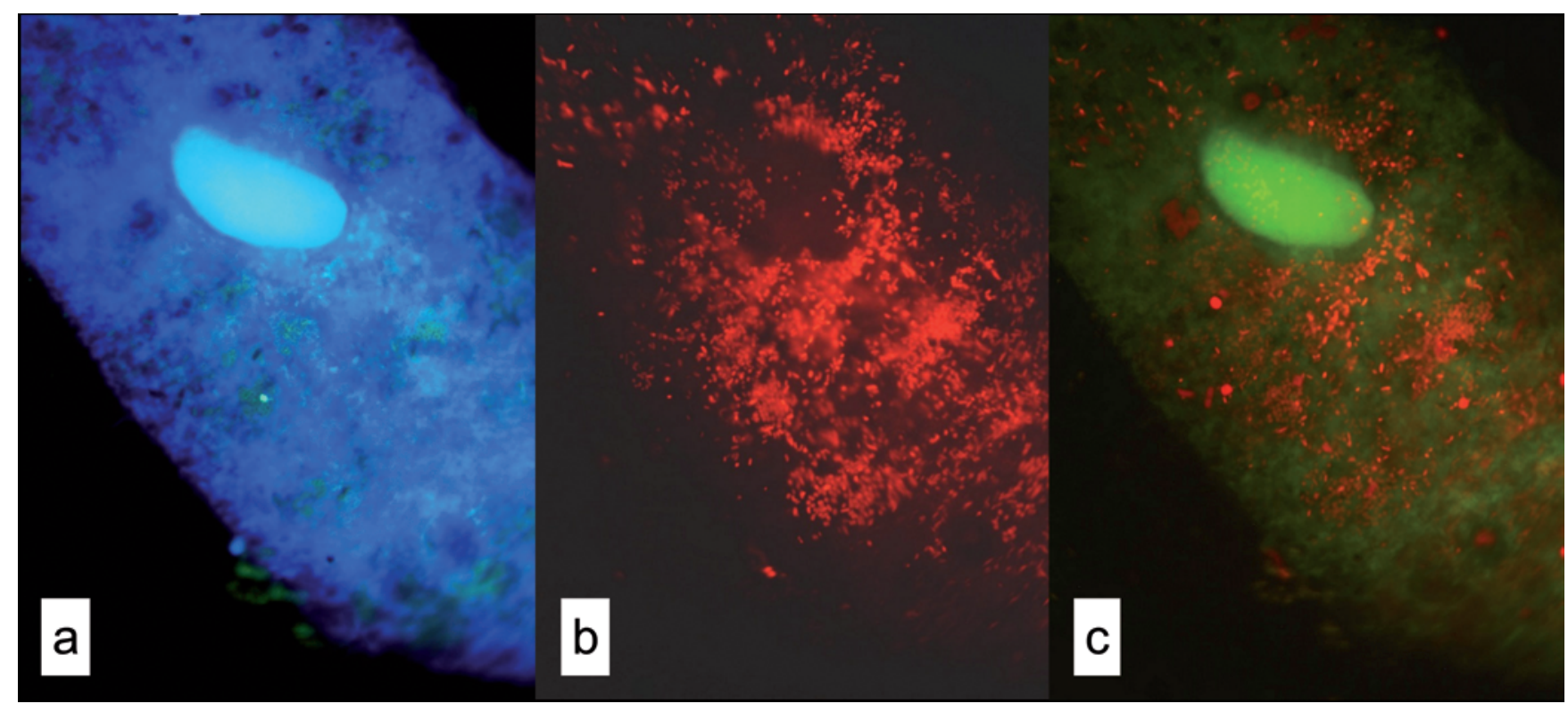

Fig. 8. Spirostomum teres in Alchichica on July 2013 (epifluorescence microscope, Leica DMLB). a) DAPI filter set (A); b) Phycobilin filter set (Y3); c) Chlorophyll $a$ filter set (I3). $1 \equiv 10 \mu \mathrm{m}$.

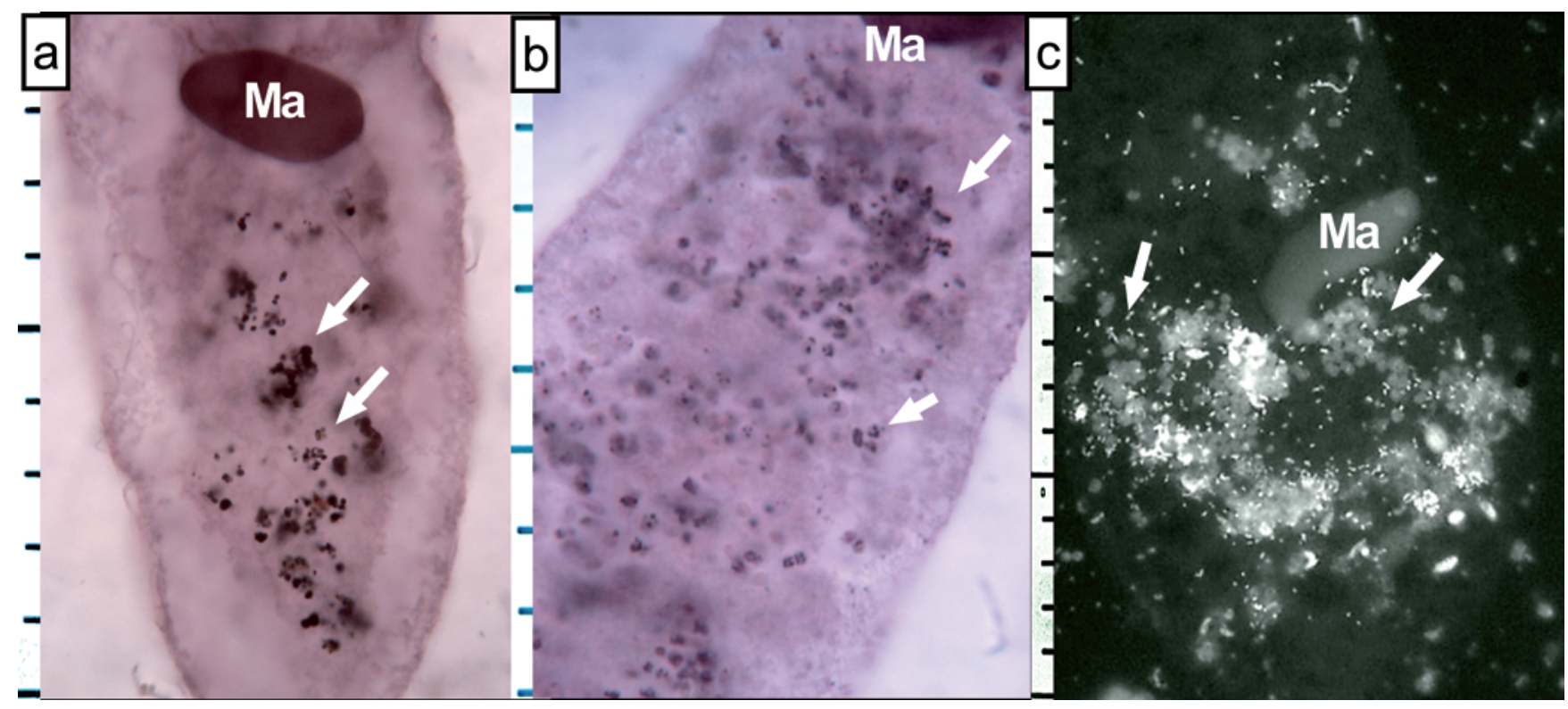

Fig. 9. Lake Alchichica Spirostomum teres with apparent purple sulphur bacteria in Protargol stain a) 4/12/2012, 36.5 m; b) 19/11/14, 38 m, and in infrared autofluorescence b) $19 / 11 / 14,38 \mathrm{~m} .1 \equiv 10 \mu \mathrm{m}$.

both with traces of DO (0.1 through $\left.0.2 \mathrm{mgL}^{-1}\right)$ and at an anaerobic bottom. Also according to the occurrence of $S$. teres (percentage of positive samples within a logarithmic scale of concentration intervals), the ciliate preferred nitrate concentrations between 0.6 and 2.5 $\mu$ molL ${ }^{-1}$ while upon concentrations over $6.3 \mu \mathrm{molL}^{-1}$ the ciliate was not observed.
The same plot but applying the concentration of nitrite (Fig. 13), a possible respiration product, did not give clear results; nitrites $>1 \mu \mathrm{mol} \mathrm{L}{ }^{-1}$ coexisted with $\mathrm{DO}>1 \mathrm{mg} / \mathrm{l}$ but the ciliate was extremely scarce in such conditions. According to the occurrence of $S$. teres, the ciliate preferred nitrite concentrations between 0.1 and $1 \mu \mathrm{mol} \mathrm{L}{ }^{-1}$ while hypolimnetic $S$. teres maximums were 


\begin{tabular}{|c|c|c|c|c|c|c|c|c|}
\hline \multirow{3}{*}{$\begin{array}{l}\text { lake } \\
\text { Alchichica }\end{array}$} & \multirow{3}{*}{$\begin{array}{l}\text { date } \\
25 / 10 / 2011\end{array}$} & \multirow{3}{*}{$\begin{array}{l}\text { depth } \\
29\end{array}$} & \multirow{2}{*}{$\begin{array}{c}\text { APP } \\
\text { cells } \mathrm{mL}^{-1}\end{array}$} & \multirow{2}{*}{$\begin{array}{l}\mathrm{N} \\
\text { cells }\end{array}$} & \multirow{2}{*}{\multicolumn{2}{|c|}{$\begin{array}{c}\text { F } \\
10^{3} \mathrm{~nL} \text { ciliate }^{-1} \mathbf{h}^{-1}\end{array}$}} & \multirow{2}{*}{\multicolumn{2}{|c|}{$\begin{array}{c}\text { G } \\
\text { APP } \text { ciliate }^{-1} h^{-1}\end{array}$}} \\
\hline & & & & & & & & \\
\hline & & & $1.96 \times 10^{5}$ & 7 & 0.80 & 0.71 & 217 & 195 \\
\hline Alchichica & $15 / 11 / 2011$ & 30 & $2.20 \times 10^{5}$ & 7 & 0.41 & 0.18 & 135 & 60 \\
\hline \multirow[t]{5}{*}{ Alchichica } & $11 / 09 / 2012$ & 25 & $5.51 \times 10^{4}$ & 37 & 1.70 & 0.56 & 136 & 45 \\
\hline & & 26 & $5.84 \times 10^{4}$ & 19 & 2.78 & 0.92 & 227 & 75 \\
\hline & & 27 & $3.21 \times 10^{4}$ & 34 & 2.28 & 0.68 & 122 & 36 \\
\hline & & 28 & $3.96 \times 10^{4}$ & 19 & 2.24 & 1.12 & 152 & 76 \\
\hline & & average & & 109 & 2.16 & 0.76 & 150 & 53 \\
\hline \multirow[t]{8}{*}{ Alchichica } & $24 / 10 / 2012$ & 27 & $1.45 \times 10^{5}$ & 4 & 1.22 & 0.33 & 196 & 54 \\
\hline & & 28 & $1.01 \times 10^{5}$ & 23 & 1.63 & 0.97 & 190 & 113 \\
\hline & & 29 & $9.29 \times 10^{4}$ & 15 & 1.87 & 0.89 & 198 & 95 \\
\hline & & 30 & $4.45 \times 10^{4}$ & 18 & 2.12 & 1.14 & 116 & 62 \\
\hline & & 31 & $3.93 \times 10^{4}$ & 13 & 2.21 & 0.98 & 111 & 49 \\
\hline & & 32 & $3.52 \times 10^{4}$ & 23 & 1.97 & 1.25 & 96 & 60 \\
\hline & & 33 & $2.93 \times 10^{4}$ & 29 & 2.14 & 1.25 & 93 & 54 \\
\hline & & average & & 125 & 1.96 & 1.08 & 132 & 72 \\
\hline \multirow[t]{4}{*}{ La Preciosa } & $26 / 10 / 2011$ & 26 & $4.36 \times 10^{5}$ & 21 & 1.18 & 0.82 & 595 & 414 \\
\hline & & 27 & $1.53 \times 10^{5}$ & 14 & 1.50 & 1.46 & 334 & 327 \\
\hline & & 28 & $8.44 \times 10^{4}$ & 1 & 2.84 & & 384 & \\
\hline & & average & & 36 & 1.35 & 1045 & 488 & 369 \\
\hline \multirow[t]{6}{*}{ La Preciosa } & $12 / 09 / 2012$ & 19 & $2.06 \times 10^{5}$ & 96 & 1.40 & 0.65 & 307 & 141 \\
\hline & & 20 & $1.40 \times 10^{5}$ & 72 & 2.13 & 1.03 & 326 & 158 \\
\hline & & 21 & $1.23 \times 10^{5}$ & 50 & 3.65 & 0.94 & 490 & 127 \\
\hline & & 22 & $6.09 \times 10^{4}$ & 20 & 2.19 & 0.75 & 162 & 56 \\
\hline & & 23 & $2.47 \times 10^{4}$ & 4 & 1.74 & 1.72 & 60 & 60 \\
\hline & & average & & 242 & 2.15 & 0.85 & 334 & 135 \\
\hline \multirow[t]{4}{*}{ La Preciosa } & $25 / 10 / 2012$ & 23 & $1.24 \times 10^{5}$ & 3 & 1.24 & 0.51 & 192 & 79 \\
\hline & & 24 & $2.09 \times 10^{4}$ & 17 & 1.11 & 0.30 & 57 & 15 \\
\hline & & 25 & $4.61 \times 10^{4}$ & 1 & 0.48 & & 43 & \\
\hline & & average & & 21 & 1.09 & 0.31 & 76 & 24 \\
\hline La Cruz & $25 / 06 / 2010$ & experiment & $3.50 \times 10^{5}$ & 40 & 0.275 & 0.065 & 115 & 27 \\
\hline
\end{tabular}




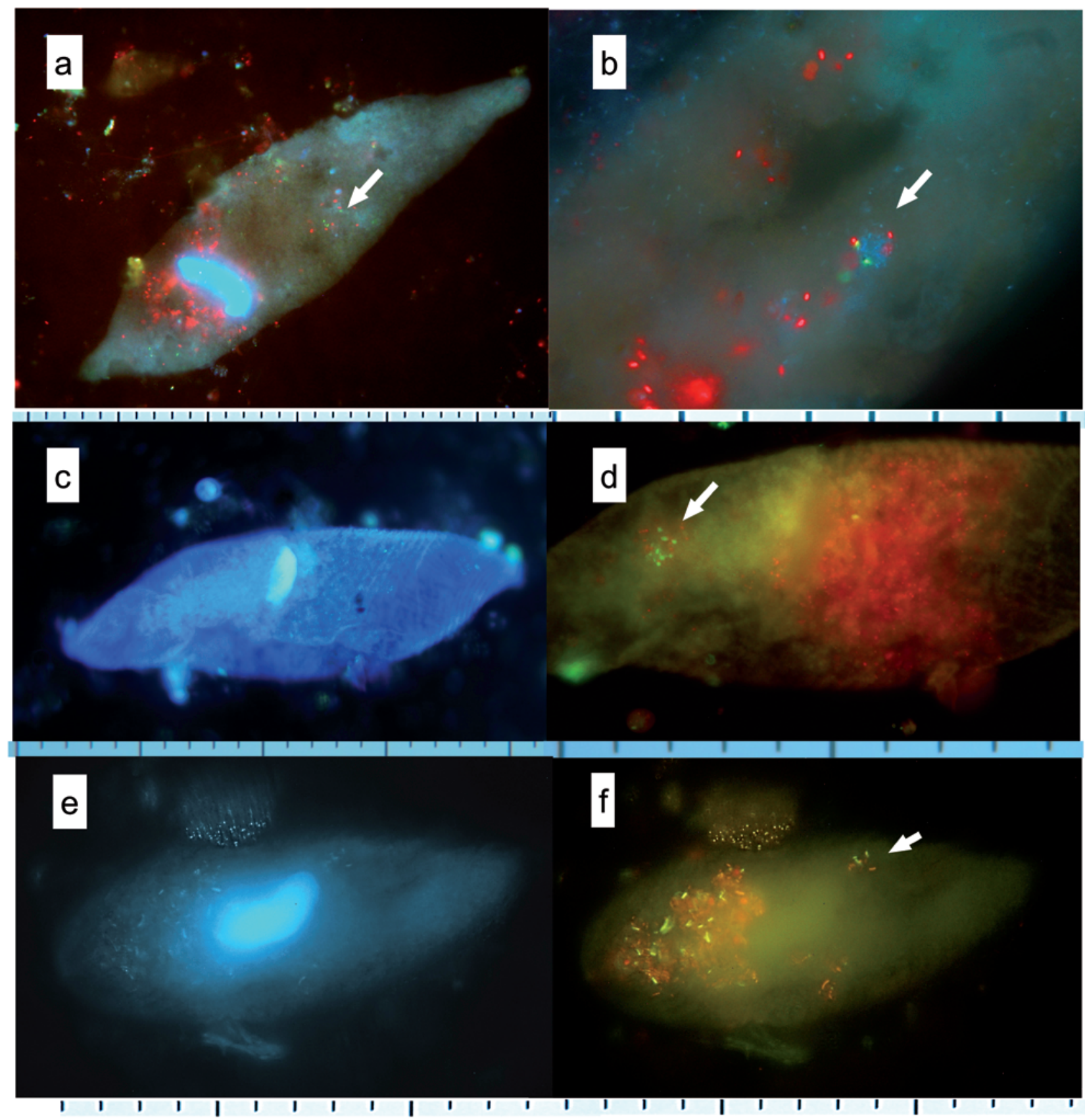

Fig. 10. Feeding experiments with FLB in Lake Alchichica (a, b), La Preciosa (c, d) and Lake de la Cruz (e, f). Triple DAPI/FITC/CY3 set $(\mathbf{a}, \mathbf{b})$; DAPI set (c, e), Chlorophyll $a$ / FITC set. Arrow: Just filled vacuole. $1 \equiv 10 \mu \mathrm{m}$.

observed between 1 and $2 \mu \mathrm{molL}^{-1}$. The ciliate occurrence was higher again over $2 \mu \mathrm{mol} \mathrm{L} \mathrm{L}^{-1}$ in the completely anaerobic conditions but the ciliate numbers were not considerably higher in such conditions.

From the point of view of picoplankton source of feed (Fig. 14), S. teres was observed upon APP num- bers varying roughly two orders of magnitude $\left(2 \times 10^{4}\right.$ to $2 \times 10^{6}$ cells $\mathrm{mL}^{-1}$ ) with occurrence peaking within $6 \times 10^{4}$ to $1 \times 10^{5}$ cells $\mathrm{mL}^{-1}$ (logarithmic scale of categories was applied). In case of HPP, the registered optimum was observed round $1.4 \times 10^{6}$ cells $\mathrm{mL}^{-1}$, typically covering the interval $7.8 \times 10^{5}$ to $2.8 \times 10^{6}$ cells 


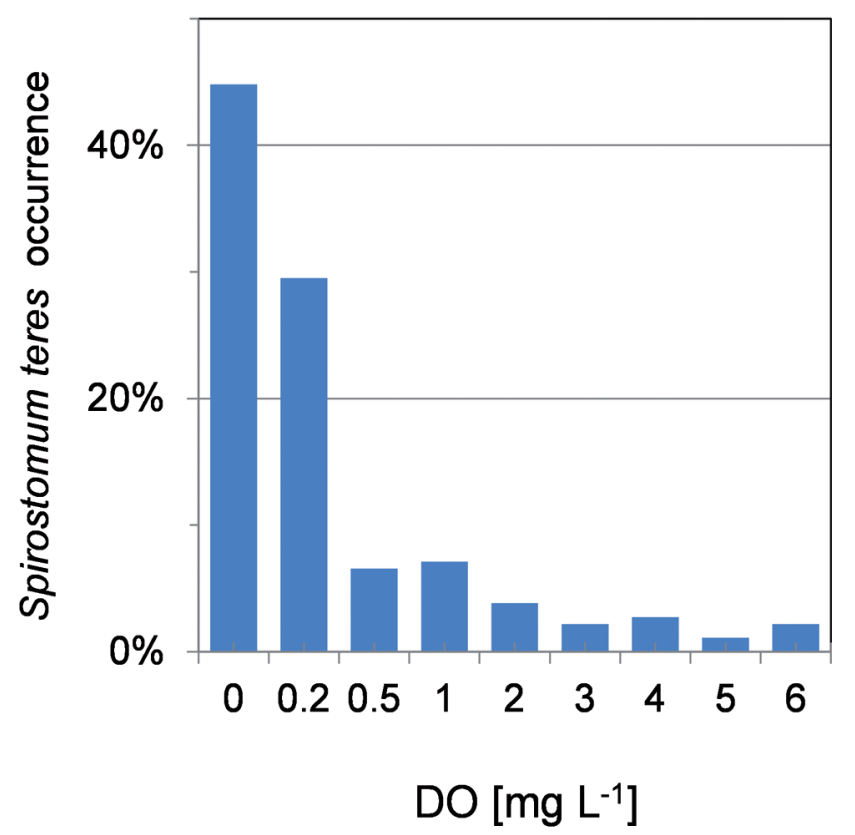

Fig. 11. Spirostomum teres occurrence (\%) in habitats defined by DO concentration $\left(\mathrm{mgL}^{-1}\right)$.

$\mathrm{mL}^{-1}$ (occurrence graph is not shown but dots in the Fig. 4 represent APP vs. all HPP data). The lowest HPP numbers were observed in the anaerobic hypolimnion while the highest ones in the oxycline.

In the plot of $S$. teres numbers against PAR and APP (Fig. 15) we could confirm that the ciliate occurrence upon above mentioned APP numbers is also supported with the available radiation in the layer / habitat, excluding the samples from uncomplete mixing event. According to occurrence, $S$. teres preferred PAR between 0.04 and $0.6 \%$, with slight preference for 0.2 to $0.6 \%$ interval. However, the occurrence of $S$. teres was also considerable in the dark hypolimnion and bottom. While the ciliate was more common in the hypolimnion, higher numbers were found in above the bottom-layer.

The dbRDA analysis of the Lake Alchichica samples where $S$. teres was present covered the layers from 21 to 61 meters (the very bottom). The results (pooled in the Fig. 16) show that the first axis of the ordination (dbRDA1), explained the higher percentage of the variation $(88.6 \%)$, and was polarized by the concentrations of dissolved reactive phosphorus (DRP) and nitrate $\left(\mathrm{NO}_{3}^{-}\right)$. The second axis (dbRDA2) explained a much smaller proportion of the variation $(7.8 \%)$ and can be associated to the oxic-anoxic gradient. The abundance of HPP and $S$. teres is associated to microaerophilic and anoxic phosphorus-rich environments with higher nitrite $\left(\mathrm{NO}_{2}^{-}\right)$and ammonium $\left(\mathrm{NH}_{3}\right)$ concentrations. However, in the ordination plot APP is located in the opposite side of DRP, in environments with the lowest concentrations of phosphorus and with a higher concentration of oxygen and nitrate within the oxic-anoxic gradient.

\section{DISCUSSION}

\section{Spirostomum teres identification}

Morphologically, the ciliates from all three lakes showed the same characteristics and, if observed in vivo, they were brown-yellowish with cortical granules but almost without visible large food particles that could change its colour.

Both in DAPI and protargol treated samples, the ciliature, membranells and morphology of cytostoma were in good agreement with the $S$. teres Cláparède \& Lachmann, 1858 description (López-Ochoterena 1966; Dragesco and Dragesco Kerneis 1986; Foissner et al. 1992; Şenler and Yildiz 2004; Fernandes and da Silva-Neto 2013; Boscaro et al. 2014; Shazib et al. 2016, 2019). However, the macronucleus was found more elongated and curved although not in such extent as for $S$. yagiui Shigenaka, 1959. It should not be so surprising because the morphological species $S$. teres contains several molecular clades (Boscaro et al. 2014; Shazib et al. 2016, 2019), which could be related to different environments. But it is quite strange that almost the same morphology was observed in two Mexican populations, one from a hyposaline lake Alchichica $\left(9 \mathrm{~g} \mathrm{~L}^{-1}\right)$, the other from a freshwater lake La Preciosa $\left(1.1 \mathrm{~g} \mathrm{~L}^{-1}\right)$ and from a karstic lake La Cruz (Cuenca, Spain).

\section{Spirostomum teres annual cycle and stratification}

During last decade, the interest of the protozoologists has turned to the so called rare biosphere including species able to survive in extreme conditions, e.g. anaerobic ones, that are present in the ecosystem but outside their specialised niche and/or following special change in environmental conditions appeared below common method detection limits (Weisse 2014). However, with some exceptions, the studies in medium to large stratified lakes avoided to quantify protists in anoxic hypolimnia with microaerophilic / anaerobic ciliates while the studies on small ponds and lakes, in 

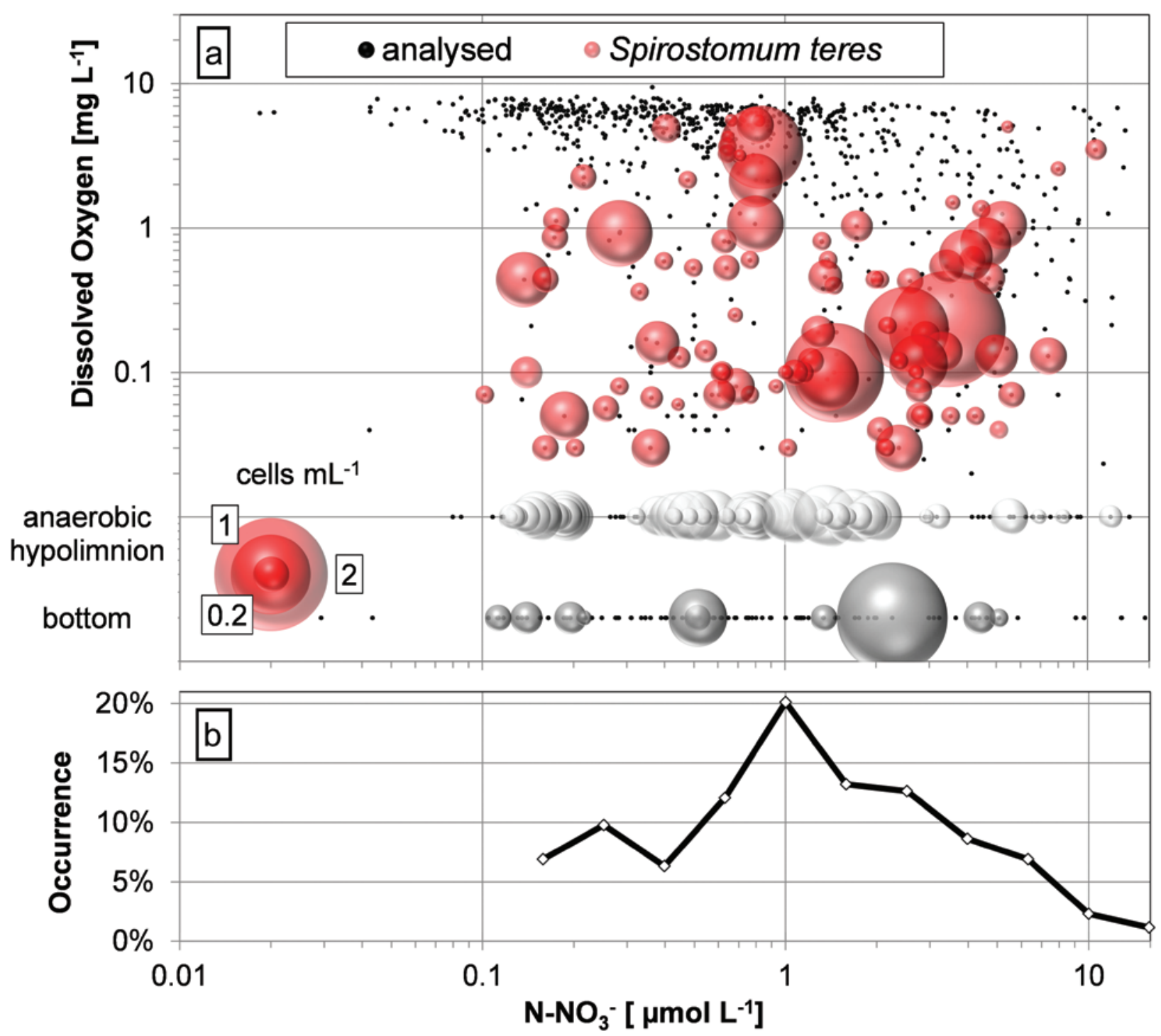

Fig. 12. a) Spirostomum teres numbers plot [cells $\left.\mathrm{mL}^{-1}\right]$ against dissolved oxygen, $\mathbf{D O}\left[\mathbf{m g} \mathbf{L}^{-1}\right] v s$. nitrate nitrogen $\mathbf{N O}_{3}^{-}\left[\mu \mathrm{molL}{ }^{-1}\right]$, and all analysed DO/nitrate data, b) Species occurrence in habitats, in which $S$. teres was found (in the logarithmic scale of nitrate nitrogen concentration).

particular meromictic and eutrophic ones were abundant (compare Madoni 1990; James et al. 1995; Hadas and Berman 1998; Peštová et al. 2008; BautistaReyes and Macek 2012; Sánchez-Medina et al 2016 vs. Finlay 1981; Bark 1985; Psenner and Schlott-Idl 1985; Neidl 1989; Madoni 1991; Guhl et al. 1994; Finlay and Esteban 2009; Oikonomou et al. 2014, 2015; Tirjaková et al. 2016). It explained why we are lacking data to be compared on the ciliate of interest from an oligomesotrophic anoxic environment.
Migration of naturally benthic organisms was proposed and proven as a source of microaerophilic ciliates, including $S$. teres in an anoxic hypolimnion and oxycline in small water bodies (Bark 1981, 1985; Finlay 1981; Madoni 1991; Finlay et al. 1996; Finlay and Esteban 2009). Definitively, $S$. teres distribution in the water column layer of Lake Alchichica was tightly connected with oxygen stratification (Figs. 3-5 and 11-12), and also the bottom population has been observed regularly until 2009 (isolated observation occurred also in 2011 

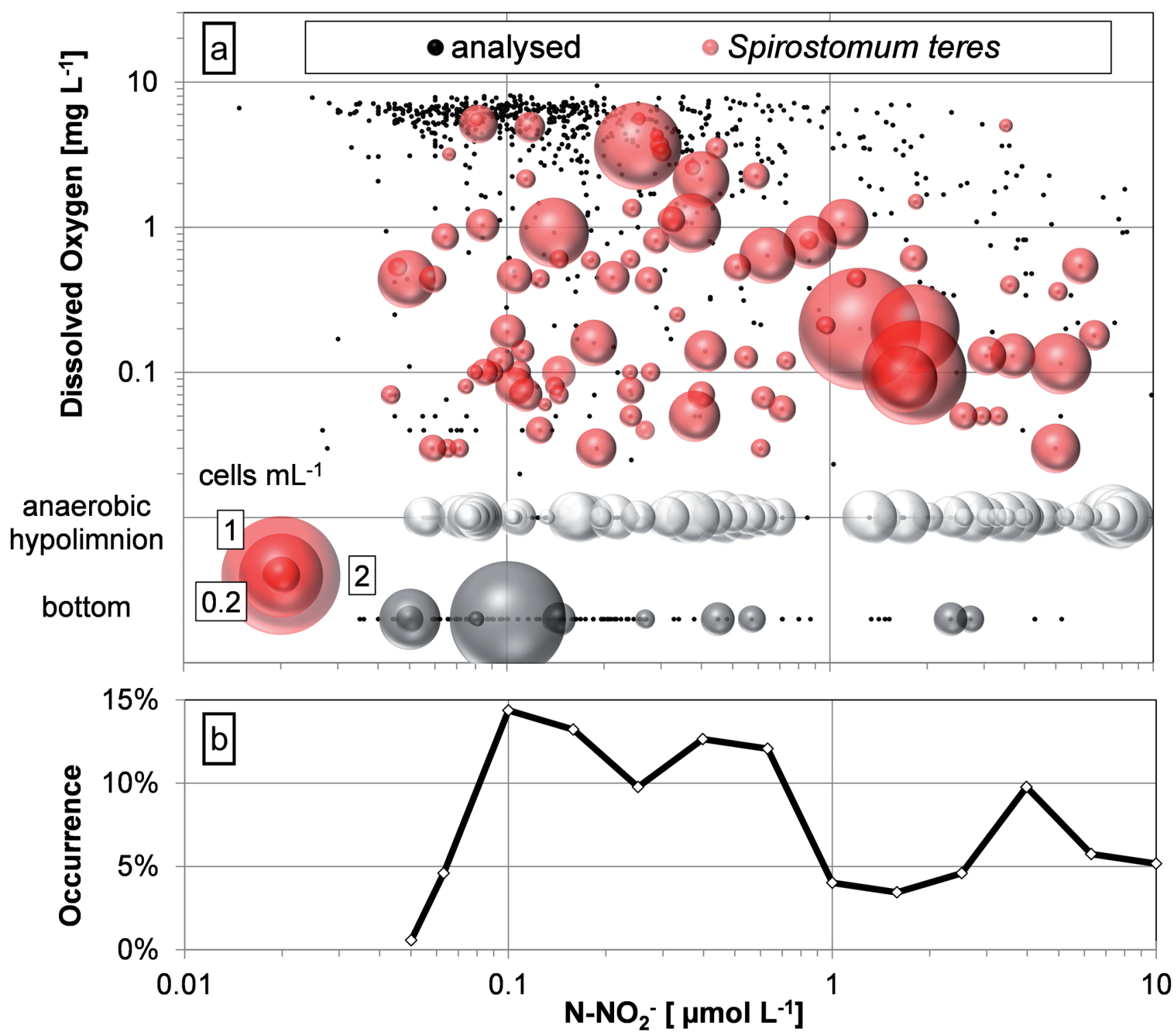

Fig. 13. a) Spirostomum teres numbers plot [cells $\left.\mathrm{mL}^{-1}\right]$ against dissolved oxygen, $\mathbf{D O}\left[\mathrm{mg} \mathrm{L}^{-1}\right]$ vs. nitrite nitrogen $\mathbf{N O}_{2}^{-}\left[\mu \mathrm{molL}{ }^{-1}\right]$, and all analysed DO/nutrients data plot, b) Species occurrence in habitats, in which $S$. teres was found (in the logarithmic scale of nitrite nitrogen concentration).

and 2016). Apparently, during last years the redox potential in the above bottom layer has been dropping (the robust data covering the study are not available) and the conditions have become unsupportable for the ciliate. But the studies of above mentioned authors were based on annual migration by less than $10 \mathrm{~m}$ within the water column or below the duckweed surface cover (Madoni 1991) comparing to 20 to $40 \mathrm{~m}$ distance to the bottom of $60 \mathrm{~m}$ in lake Alchichica. One must accept also the dial migration of $S$. teres within the water column that was proposed to be as much as 5 (10) m (Bark 1981) and well documented in a eutrophic gravel pit lake (Rossberg and Wickham 2008). In the latter one, the mean depth of population varied up $1 \mathrm{~m}$ comparing day and night, even though taking into account changes in the width of the layer colonised by $S$. teres, real migration was wider. However, it should not explain bottom- and oxycline-population communication in our deep lake. It seems that the oxycline / anoxic hypolimnion Alchichica population was proliferating separately and/or, hy- 
pothetically, it was related to littoral or less deep parts of the lake. In the hypolimnion of Lake Alchichica, the temperature was increasing gradually to $15.3^{\circ} \mathrm{C}$ during the last two decades that has reached almost the optimum temperature for $S$. teres growth (Laybourn and Finlay 1976, Finlay 1977) giving, theoretically, generation time of $<100 \mathrm{~h}$. Under such conditions, the respiration would increase as well. Statistical significance can hardly be obtained for any limnological variable to be linked as explicative for $S$. teres distribution and abundance due to the fact that thermal stratification, the position of the oxycline, and the deep chlorophyll maximum (DCM) were tightly co-correlated in Lake Alchichica. In this regard, a dbRDA ordination analysis was the best approach in order to determine to what extend environmental variables can explain the differences in the abundance of $S$. teres, APP and HPP in the abundance matrix (Fig. 16). The dbRDA ordination shows that $S$. teres was related to microaerophilic and anoxic phosphorus-rich environments. On the other hand, $S$. teres is supposed to be microaerophilic, i.e. oxygen respiring upon low DO concentrations while it is able to slow down oxygen consumption with decreasing oxygen tension - so called oxygen conformer (Finlay 1977). However, our data demonstrated the occurrence, even with higher abundance, of $S$. teres in anoxic conditions, as it has been proven in many studies (e.g., Finlay 1981, Psenner and Schlott-Idl 1985, Madoni 1991, Sánchez-Medina et al. 2016).

Until now, the nitrate respiration, i.e. nitrite production was proven for Loxodes spp. (Finlay 1985) and other protozoa (Hadas et al. 1992). In the case of S. teres, Psenner and Schlott-Idl (1985) observed apparent relation of the ciliate peaking and nitrate drop coinciding with nitrite peak (not quantified) in lake Piburgersee. In the same lake, Neidl (1989) tried to correlate nitrite data with $S$. teres occurrence but as he had analysed only nitrates, he applied nitrite profiles taken during preceding year. In lake Alchichica, many samplings of nutrients were not sufficiently numerous throughout the water column to describe local nitrite peaks, cleared by a linear interpolation of lacking stratification data (except, e.g. data in Fig. 4) but it is apparent that the hypolimnion $S$. teres maximums coincided with higher nitrate concentrations (Fig. 12). It was confirmed in the dbRDA ordination analysis showing that the abundance of $S$. teres along with HPP is associated with higher nitrite $\left(\mathrm{NO}_{2}^{-}\right)$and ammonium $\left(\mathrm{NH}_{3}\right)$ concentrations. The relationship would not be observed directly, since the activity of nitrogen cycle-bacteria was proven in such layers (Pajares et al. 2017). Very recently, a transcriptome of proteins involved in rhodoquinol-dependent fumarate reduction to respire in the oxygen-depleted habitats were found in a mixotrophic zoochlorella bearing S. semivirescens (Hines et al. 2018). Even though the $S$. teres occurrence shows preferred PAR between 0.04 and $0.6 \%$, with slight preference for 0.2 to $0.6 \%$ interval, the statistical tests may not be applied. Such values might have a considerable measurement error during cloudy days when a low absolute PAR was registered. Moreover, the occurrence of $S$. teres was also considerable in the near-zero illumination /dark hypolimnion and bottom showing even higher abundances.

Spirostomum sp. occurrence in the environment was apparently related to a deep chlorophyll maximum. Rossberg and Wickham (2008) observed the typical Spirostomum sp. layer just above the DCM but in that case, it was form by Chromatium-like purple sulphur bacteria. In Lake Alchichica, DCM was composed, generally, by large diatoms Cyclotella alchichicana, accompanied by a minute $C$. choctawhatcheeana, chlorophytes Monoraphidium minutum and, frequently, by a local peak of picocyanobacteria. However, the in situ registered fluorescence did not reveal cyanobacteria peaking: "phycoerythrin" stratification resembled that of diatoms; only cyanobacterial colonies/aggregates were apparently registered as "phycocyanin". Just within the DCM, it was possible to observe $S$. teres, e.g., in July when the thermocline was very thick presenting DO and PAR gradient there. DO dropped to zero just around DCM layer coinciding with about $0.1 \%$ PAR. Typically, $S$. teres maximums were found 2 to 4 meters below DCM / zero DO but still above the layer with abundant Thiocapsa-like purple bacteria, depending on even lower redox potential (Fig. 4). Due to the lack of chlorophyll data from the dark layers (untill 2012), we were not able to use pigment data in the statistical analysis. Different situation was found in Lake La Preciosa, where $S$. teres occupied the layers just above the DCM but below zero DO (Fig. 5). In contrary, Tirjaková et al. (2016) found abundant $S$. teres within cyanobacterial blooms with pretty high DO saturation (> 50\%); no data on bacteria and picocyanobacteria were measured. Also Beaver and Crisman (1989) stated primarily the Spirostomum spp. surrounding community as "plankton of very productive ponds and lakes". Bacteria with IR fluorescence (supposingly anoxigenic photosynthetic bacteria in chains of cells with much brighter fluorescence than that of purple bacteria from Alchichica) apparently did not serve as a feeding source, they were 

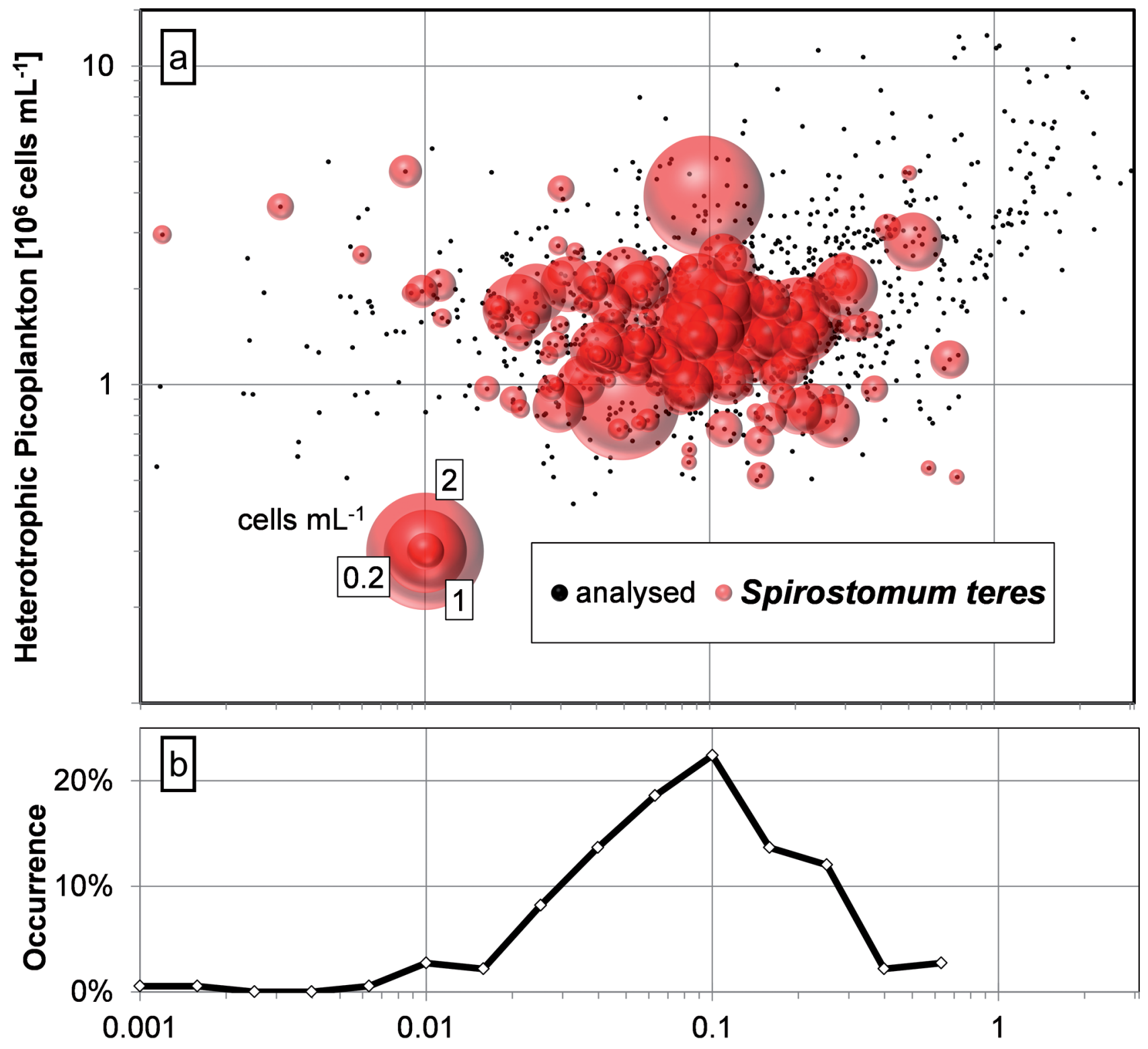

\section{Autotrophic Picoplankton [106 cells $\left.\mathrm{mL}^{-1}\right]$}

Fig. 14. a) Spirostomum teres numbers plot [cells $\left.\mathrm{mL}^{-1}\right]$ against autotrophic, $\mathbf{A P P} v s$. heterotrophic picoplankton, $\mathbf{H P P}\left[\mathbf{c e l l s} \mathbf{m L}^{-1}\right]$, and all analysed APP/HPP data plot, b) Species occurrence in habitats, in which S. teres was found (in the logarithmic scale of APP).

toxic and/or occupied the layers with the environmental variables, which already did not support the ciliate growth. Either in Lake La Cruz (Spain) or La Preciosa (Mexico), S. teres did not penetrate the maximum of photosynthetic anoxygenic bacteria, observed via their autofluorescence registered with infrared camera.

Even though Spirostomum spp. have been study exhaustively from the point of view of prokaryotic symbionts (Fokin et al. 2005), there is a lack of information on their feeding behaviour and data on their feeding rate. Adl et al. (2019) declared the genus as bacterivorous while other classified it as algivorous / omnivorous (López-Ochoterena 1966, Bick 1958, Finlay 1981), deducing bacterivory (Psenner and Schlott-Idl 1985) and again, Finlay and Esteban (2009) defined $S$. teres as a mainly bacterivorous, function- 

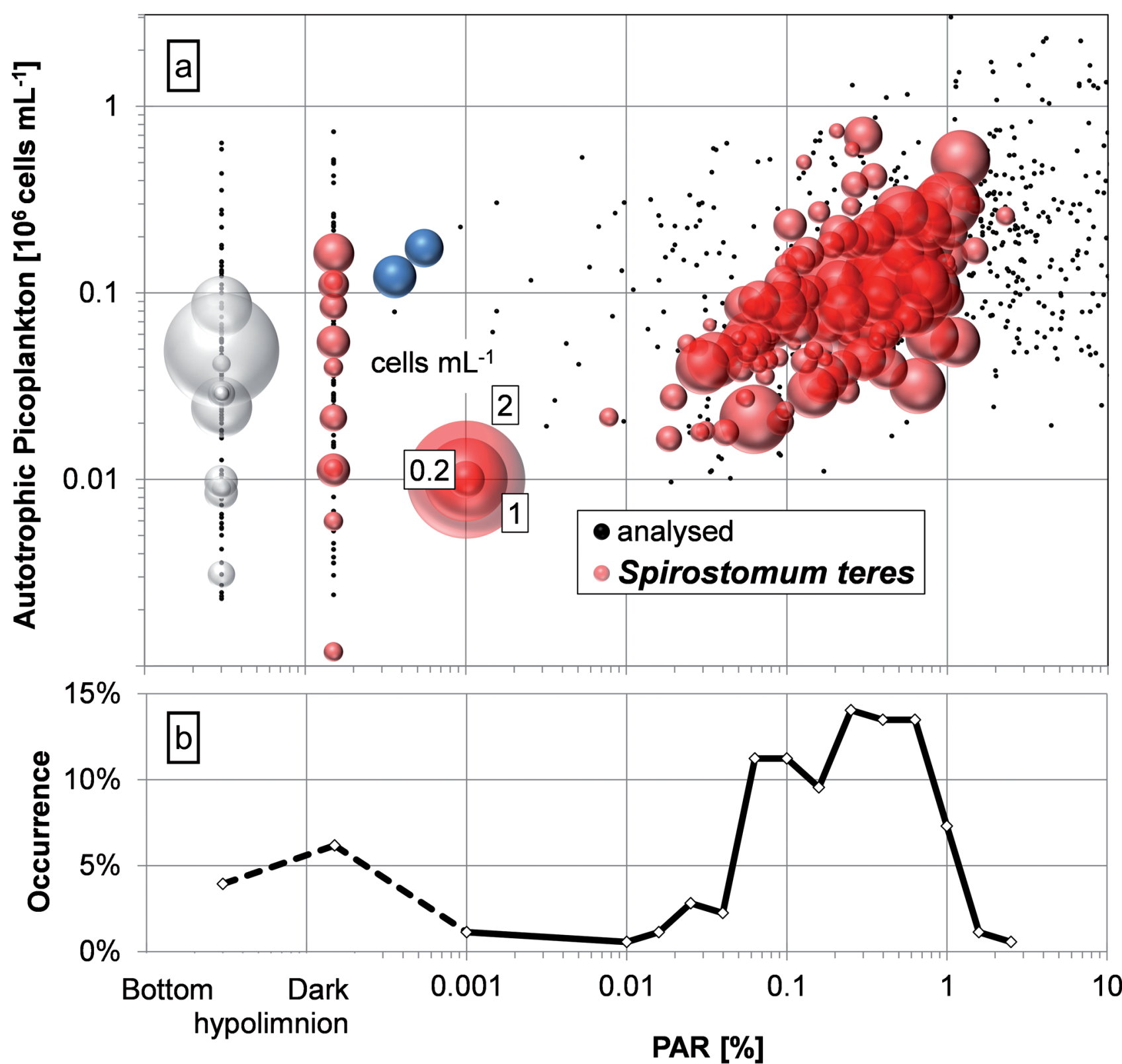

Fig. 15. a) Spirostomum teres numbers plot [cells $\mathrm{mL}^{-1}$ ] against Photosynthetically Active Radiation, PAR [\%] $v s$. autotrophic picoplankton, APP [cells $\mathbf{~ m L}^{-1}$ ], and analysed PAR/APP data plot; blue bubbles mark the samples from the event of incomplete mixing (January); b) Species occurrence in habitats, in which $S$. teres was found (in the logarithmic scale of PAR).

ally complex upstream filter feeder. On the other hand, Foissner et al. (1992) stated S. teres as a bacterivorous, particularly purple- and green-sulphur bacteria feeder, which ingested even minute chrysophytes, diatoms and desmids. We have observed during the study nearly all these organisms inside the cells: Populations from all three lakes ingested in different proportion minute plankton bacteria, purple sulphur bacteria, diatoms $C$. choctawhatcheeana, green algae Monoraphidium spp. and Oocystis spp. However, the observed prey that was almost dominant for the populations were the picocyanobacteria. It is possible that the authors, which were not using fluorescence microscopy for the ciliate observations, were not be able to distinguish them either for the ciliate pigmentation or for the colour of cyanobacteria different to blue-green: 


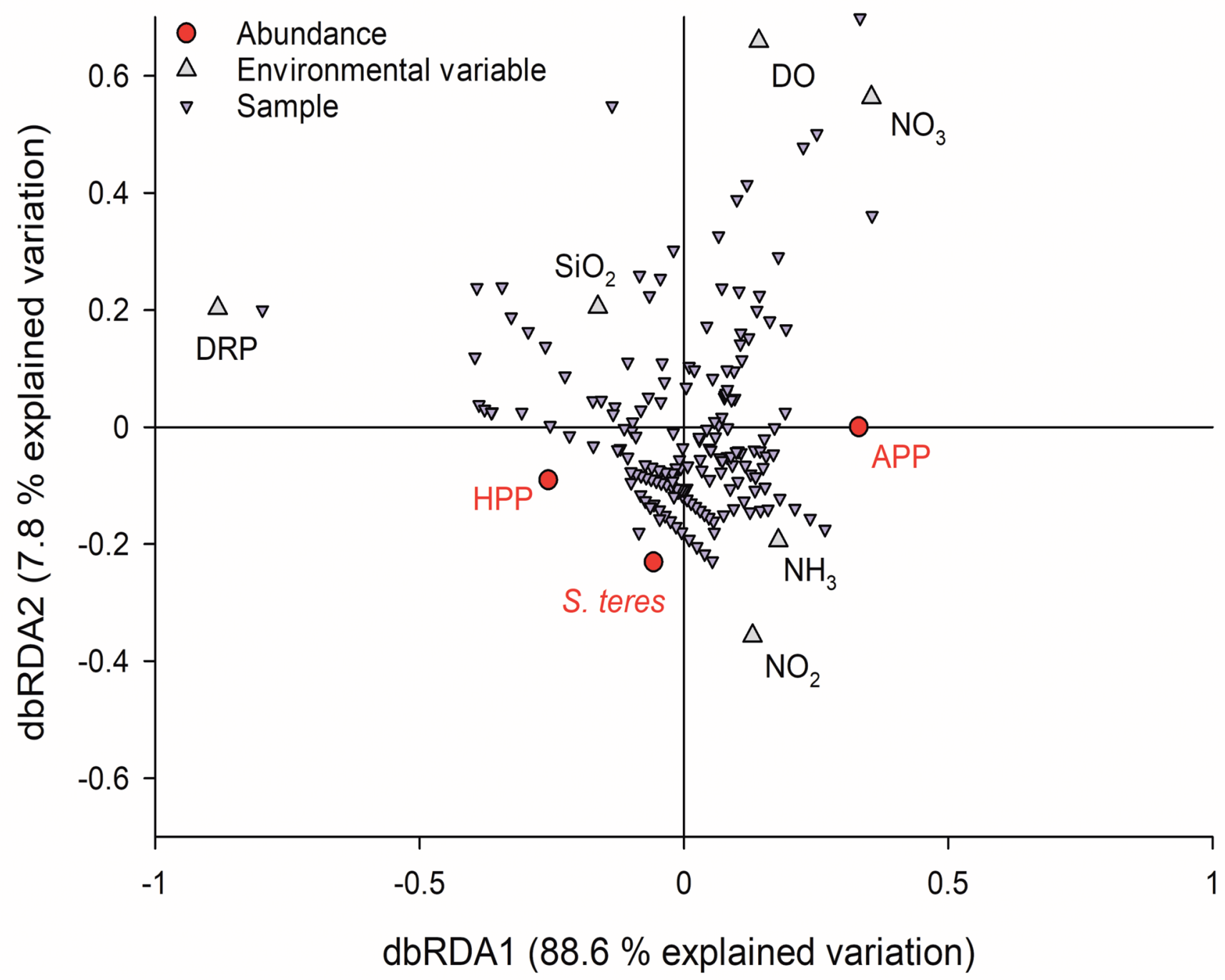

Fig. 16. a) Plot of distance-based redundancy analysis (dbRDA) of Spirostomum teres (S. teres), autotrophic picoplankton (APP) and heterotrophic picoplankton (HPP) abundance using environmental data as predictor variables, for Lake Alchichica. Environmental variables: Concentrations of dissolved oxygen (DO), ammonium $\left(\mathbf{N H}_{3}\right)$, nitrite $\left(\mathbf{N O}_{2}\right)$, nitrate $\left(\mathbf{N O}_{3}\right)$, dissolved reactive phosphorus (DRP) and silicon $\left(\mathrm{SiO}_{2}\right)$.

isolated Alchichica and La Preciosa picocyanobacteria were mainly purple to violet (Callieri et al. 2013) and La Cruz cyanobacteria were observed yellowish on the membrane filters. On the other hand, all cyanobacteria from the $S$. teres layers showed both bright chlorophyll $a$ and phycobilins fluorescence while the surface picocyanobacteria were observed almost only through phycobilins. Curiously, according to dbRDA ordination analysis, $S$. teres and HPP abundances are associated to low oxygen and high DRP concentrations accompanied by nitrite and ammonium while the ordination plot of APP is located in the opposite side with the lowest DRP and higher DO and nitrate concentrations within the oxic-anoxic gradient (Fig. 16). Although it was possible to find $S$. teres in the layers with DO up to $6 \mathrm{mgL}^{-1}$, we were obliged to follow strictly the recommendations of Massana and PedrósAlió (1994) to maintain the feeding experiments upon anoxic conditions. If the BOD bottles were not filled passing minimum three their volumes with the sample coming from the tube of the sampler, $S$. teres did not show any activity. In Lake La Cruz where small amount of the sample had been obtained via pumping and the washing-out had not been applied, we were 
not be able to keep the optimum conditions and consequently we had to measure the feeding activity upon laboratory conditions.

Average clearance rates of $S$. teres (Table 1) from significantly robust samplings of Mexican lakes (over 100 examined cells per sampling) were found around $2000 \mathrm{~nL} \mathrm{cell}^{-1} \mathrm{~h}^{-1}$, i.e. in Alchichica, APP uptake rate of 130 to 150 cells cell ${ }^{-1} \mathrm{~h}^{-1}$ but in La Preciosa, up 400 cells cell $^{-1} \mathrm{~h}^{-1}$. The estimated feeding activity in the samples with lower $S$. teres numbers was also lower. La Cruz population was less active (clearance rate $245 \mathrm{~nL}^{-} \mathrm{cell}^{-1}$ $\mathrm{h}^{-1}$, i.e. 115 cells cell ${ }^{-1} \mathrm{~h}^{-1}$ ) but it was in concordance with the lake low temperature $\left(6^{\circ} \mathrm{C}\right.$ in the maximum $S$. teres layer) that was followed in the laboratory experiments. According to Finlay (1977), S. teres is nearly inactive upon such conditions.

In absolute values, the feeding rates of $S$. teres were comparable to efficient plankton ciliates such as Halteria grandinella, which bacteria uptake rate was found 1580 cells cell ${ }^{-1} \mathrm{~h}^{-1}$ but that of APP only 210 cells cell ${ }^{-1} h^{-1}$ (Šimek et al. 1995). However, if the volume specific clearances were calculated according to Fenchel (1986), S. teres did not present an appropriate feeding activity to support its suspension feeding-derived growth upon picocyanobacteria. $H$. grandinella of a volume of $2.86 \times 10^{3} \mu \mathrm{m}^{3}$ and clearance rate of $<1200 \mathrm{~nL} \mathrm{cell}^{-1} \mathrm{~h}^{-1}$ (Šimek et al. 1995) would have specific clearance of an order of magnitude $10^{5} \mathrm{~h}^{-1}$, which classifyed it as an efficient suspension feeder, while our $S$. teres of biovolume $2.3 \times 10^{6} \mu \mathrm{m}^{3}$ and clearance rate $2000 \mathrm{~nL} \mathrm{cell}{ }^{-1} \mathrm{~h}^{-1}$ possessed specific clearance only up to $10^{3} \mathrm{~h}^{-1}$. Stentor $\mathrm{sp}$. from the same size category was found to reach a value over $10^{4} \mathrm{~h}^{-1}$. On the other hand, according to our observations, picocyanobacteria remained in the vacuoles along with FLB for a long time (over one hour) without that they were digested, which looked like the ciliate behavioural strategy (for picocynobacteria ingestion/digestion in minute ciliates, see, Dolan and Šimek 1997). Thus, S. teres should use to support the growth another carbon source, e.g. (i) products of photosynthesis of ingested picocyanobacteria, (ii) it could ingest bacteria upon higher feeding rates that APP or (iii) ingestion of larger eukaryotes such as diatoms and chlorophytes is much more important than it had been supposed.

\section{CONCLUSION}

Spirostomum teres was found growing in the pelagic / anoxic hypolimnion of an oligo- to mesotrophic monomictic hyposaline crater lake. During the first decade of monitoring, there was an apparent very bottom population of the ciliate during mixing, then the pelagic population has been developing during the stratification. However, during last years the bottom population has been gradually disappearing and there is no evidence for periodical colonization of the hypolimnion from the bottom.

Early stratification distribution of the ciliate was located several meters below the deep chlorophyll maximum (formed basically by diatoms) and below the zero DO layer; a gradient of light conditions possibly supporting oxic and/or anoxic photosynthesis was observed. Late stratification after deepening of the thermocline reduced the layers with $S$. teres population to a minimum, probably due to the drastic drop in DO and redox-potential conditions. On the other hand, the ciliate has been found repeatedly in the deep part of the lake during an uncomplete overturn.

Well defined stratification of the ciliate was apparently driven by source of feed and that of respiration. $S$. teres was found almost only upon anoxic condition but in the presence of nitrates and nitrites (possible final electron acceptor and the respiration product, respectively). Also residual PAR (below 0.1\%) was identified as possible stimuli for the population development.

The ciliate was able to proliferate in the microaerobic and anaerobic environment without presence of high numbers of prokaryotic prey. Bacteria numbers found in the $S$. teres colonised layer laid within an order of magnitude $10^{6}$ cells $\mathrm{mL}^{-1}$. Optimum picocyanobacteria numbers apparently supporting the ciliate growth laid within $6 \times 10^{4}$ to $1 \times 10^{5}$ cells $\mathrm{mL}^{-1}$. S. teres feeding upon picocyanobacteria reached clearance rate of 2000 $\mathrm{nL}$ cell $^{-1} \mathrm{~h}^{-1}$. Feeding upon purple sulphur bacteria was observed but only during the end of the lake stable stratification when the ciliate population was already dropping. The results were well comparable with those from a neighbour freshwater crater lake La Preciosa and with a meromictic karstic Lake de La Cruz (Cuenca, Spain).

On the other hand, the volume specific clearance of $S$. teres upon picocyanobacteria did not support the hypothesis that they could serve as a dominant prey along with heterotrophic bacteria. It is hypothesized that an activity of the ingested photosynthesising 
microorganisms, including eukaryotic diatoms and chlorophytes, could support $S$. teres growth.

\section{AUTHORS' CONTRIBUTION:}

Miroslav Macek wrote the manuscript and evaluated picoplankton and ciliate feeding activity, except for periods covered by coauthors mentioned below;

Ximena Sánchez Medina participated in writing of the manuscript; she was co-evaluating the ciliate occurrence in 2010 and from 2012 to 2016;

Antonio Picazo and Antonio Camacho were evaluating limnologic data and participating in laboratory feeding experiments. They carried out the statistical analysis;

Dana Peštová, Fernando Bautista Reyes, and Jorge Ricardo Montiel Hernández were evaluating the ciliate feeding activity from October 2003 to December 2005, from 2008 to 2010, and in the fall of 2011, respectively; they supported unpublished ciliate data for the study;

Javier Alcocer was partly evaluating limnologic data;

Martín Merino Ibarra was evaluating nitrogen, phosphorus and silicon data.

Acknowledgement. Support for the long-term analysis of lake Alchichica data was granted to M. Macek as UNAM DGPA/PAPIIT IN225517 (2017-2019). Research support for previous studies was granted to M. Macek through CONACYT 52387 (2007), SEP-CONACYT 79893 (2009); CONACYT 131689 (2011-2013), CONACYT Mexico - DLR Germany bilateral grant 1203801, DGAPA IN208502 (2003-2005), DGPA IN207206 (2006-2008), DGAPA IN222709 (2009-2011), and as internal UNAM FES grants PAPCA 2002-2003, PAPCA 2003-2004, PAPCA 2006, and PAPCA 2009. Blanca Perez Uz and Pablo Quintela Alonso discussion improved an early stage of Spirostomum teres ecology investigations during the sabbatical stay of M. Macek at La Universidad Complutense, Madrid, supported as a UNAM grant PASPA 2015.

J. Alcocer was granted by CONACYT 41667, DGAPA IN204597, and DGAPA IN210806-3. PhD studies of D. Peštová were granted as a scholarship of the Foreign Affairs Secretary of United States of Mexico; PhD studies of F. Bautista Reyes and MS studies of X. Sánchez Medina were supported by a CONACYT scholarship.

The research would have been impossible without the work of sampling team composed from UNAM colleagues and students; in particular we thank to Dr Luis A. Oseguera Pérez. Chemical analyses were carried out by M.S. Sergio Castillo Sandoval.

\section{REFERENCES}

Adl S. M., Bass D., Lane C. E., Lukeš J., Schoch C. L., Smirnov A., Agatha S., Berney C., Brown M. W., Burki F., Cárdenas P., Čepička I., Chistyakova L., del Campo J., Dunthorn M., Edvardsen B., Eglit Y., Guillou L., Hampl V., Heiss A. A., Hoppenrath M., James T. Y., Karnkowska A., Karpov S., Kim E., Kolisko M., Kudryavtsev A., Lahr D. J. G., Lara E., Le Gall L., Lynn D. H., Mann D. G., Massana R., Mitchell E. A. D., Morrow C., Park J. S., Pawlowski J. W., Powell M. J., Richter D. J., Rueckert S., Shadwick L., Shimano S., Spiegel F. W., Torruella G., Youssef N., Zlatogursky V., Zhang Q. (2019). Revisions to the classification, nomenclature, and diversity of eukaryotes. J. Eukaryot. Microbiol. 66: 4-119

Armienta M. A., Vilaclara G., De la Cruz-Reyna S., Ramos S., Ceniceros N., Cruz O., Aguayo A., Arcega-Cabrera F. (2008) Water chemistry of lakes related to active and inactive Mexican volcanoes. J. Volcanol. Geotherm. Res. 178: 249-258

Azam F., Fenchel T., Field J. G., Gray J. S., Meyer-Reil L., Thingstad F. (1983) The ecological role of water-column microbes in the sea. Mar. Ecol. Prog. Ser. 10: 257-263

Bark A. W. (1981) The temporal and spatial distribution of planktonic and benthic protozoan communities in a small productive lake. Hydrobiologia 85: 239-255

Bark A. W. (1985) Studies on ciliated protozoa in eutrophic lakes: 1. Seasonal distribution in relation to thermal stratification and hypolimnetic anoxia. Hydrobiologia 124: 167-176

Bautista-Reyes F., Macek M. (2012) Ciliate food vacuole content and bacterial community composition in the warm-monomictic crater lake Alchichica (México). FEMS Microbiol. Ecol. 79: 85-97

Beaver J. R., Crisman T. L. (1989) The role of ciliated protozoa in pelagic freshwater ecosystems. Microb. Ecol. 17: 111-136

Berninger U. G., Finlay B. J., Canter H. M. (1986) The spatial distribution and ecology of zoochlorellae-bearing ciliates in a productive pond. J. Protozool. 33: 557-563

Bick H. (1958) Ökologische Untersuchungen an Ciliaten fallaubreicher Kleingewässer. Arch. Hydrobiol. 54: 506-542

Bishop A. (1923) Some observations upon Spirostomum ambiguum (Ehrenberg). Q. J. Microsc. Sci. 67: 391-432

Borcard D., Gillet F., Legendre P. (2018) Numerical ecology with R. $2^{\text {nd }}$ Ed. Springer, Cham

Boscaro V., Carducci D., Barbieri G., Senra M. V. X., Andreoli I., Erra F., Petroni G., Verni F., Fokin S. I. (2014) Focusing on genera to improve species identification: revised systematics of the ciliate Spirostomum. Protist 165: 527-541

Callieri C. (2007) Picophytoplankton in freshwater ecosystems: the importance of small-sized phototrophs. Freshwater Rev. 1: 1-28

Callieri C., Coci M., Corno G., Macek M., Modenutti B., Balseiro E., Bertoni R. (2013) Phylogenetic diversity of non-marine picocyanobacteria. FEMS Microbiol. Ecol. 85: 293-301

Camacho A., Miracle M., Romero-Viana L., Picazo Mozo A., Vicente E. (2017) Lake La Cruz, an iron-rich karstic meromictic lake in central Spain. In: Ecology of Meromictic Lakes (Eds. R. D. Gulati, E. S. Zadereev, A. G. Degermendzhi). Ecological Studies (Analysis and Synthesis), vol 228, Springer, Cham,187233

Dolan J. R., Šimek K. (1997) Processing of ingested matter in Strombidium sulcatum, a marine ciliate (Oligotrichida). Limnol. Oceanogr. 43: 393-397

Dragesco J., Dragesco Kerneis A. (1986) Ciliés libres de l'Afrique intertropicale : introduction à la connaissance et à l'étude des Ciliés. Faune Tropicale 26. ORSTOM, Paris

Fenchel T. (1986) Protozoan filter feeding. Progr. Protistol. 1: 65113

Fenchel T. (2012) Protozoa and oxygen. Acta Protozool. 52: 11-20

Fernandes N. M., da Silva Neto I. D. (2013) Morphology and 18S rDNA gene sequence of Spirostomum minus and Spirostomum teres (Ciliophora: Heterotrichea) from Rio de Janeiro, Brazil. Zoologia 30: 72-79

Filonov A., Tereshchenko I., Alcocer J. (2006) Dynamic response to mountain breeze circulation in Alchichica, a crater lake in Mexico. Geophys. Res. Lett. 33: L07404 
Finlay B. J. (1977) The dependence of reproductive rate on cell size and temperature in freshwater ciliated protozoa. Oecologia 30: $75-81$

Finlay B. J. (1981) Oxygen availability and seasonal migrations of ciliated protozoa in a freshwater lake. J. Gen. Microbiol. 123: $173-178$

Finlay B. J. (1985) Nitrate respiration by Protozoa (Loxodes spp.) in the hypolimnetic nitrite maximum of a productive freshwater pond. Freshwater Biol. 15: 333-346

Finlay B. J., Esteban G. F. (1998) Planktonic ciliate species diversity as an integral component of ecosystem function in a freshwater pond. Protist 149: 155-165

Finlay B. J., Esteban G. F. (2009) Oxygen sensing drives predictable migrations in a microbial community. Environ. Microbiol. 11: $81-85$

Finlay B. J., Maberly S. C., Esteban G. F. (1996) Spectacular abundance of ciliates in anoxic pond water: Contribution of symbiont photosynthesis to host respiratory oxygen requirements. FEMS Microbiol. Ecol. 20: 229-235

Foissner W., Berger H., Kohmann F. (1992) Taxonomische und ökologische revision der Ciliaten des Saprobiensystems - Band II. Peritrichia, Heterotrichida, Odontostomatida. Informationsberichte des Bayer. Landesamtes für Wasserwirtschaft, Wasserwirtschaft, Deggendorf

Fokin S. I., Schweikert M., Brümmer F., Görtz H.-D. (2005) Spirostomum spp. (Ciliophora, Protista), a suitable system for endocytobiosis research. Protoplasma 225: 93-102

Guhl B. E., Finlay B. J., Schink B. (1994) Seasonal development ciliate communities in a eutrophic pond. FEMS Microbiol. Ecol. 14: $293-306$

Hadas O., Berman T. (1998) Seasonal abundance and vertical distribution of Protozoa (flagellates, ciliates) and bacteria in Lake Kinneret, Israel. Aquat. Microb. Ecol. 14: 161-170

Hadas O., Pinkas R., Wynne D. (1992) Nitrate reductase activity, ammonium regeneration, and orthophosphate uptake in protozoa isolated from Lake Kinneret, Israel. Microb. Ecol. 23: $107-115$

Hansen H. P., Korolef F. (1999) Determination of nutrients. In: Methods of Seawater Analysis (Eds. K. Grasshoff, K. Kremling, M. Ehrhardt). Wiley-VCH Verlag, Weinheim,159-228

Hernández-Avilés J. S., Macek M., Alcocer J., López-Trejo B., Merino-Ibarra M. (2010) Prokaryotic picoplankton dynamics in a warm-monomictic saline lake: temporal and spatial variation in structure and composition. J. Plankton Res. 32: 1301-1314

Hines H. N., Onsbring H., Ettema T. J. G., Esteban G. F. (2018) Molecular investigation of the ciliate Spirostomum semivirescens, with first transcriptome and new geographical records. Protist 169: $875-886$

Hu X., Kusuoka Y. (2015) Two oxytrichids from the ancient Lake Biwa, Japan, with notes on morphogenesis of Notohymena australis (Ciliophora, Sporadotrichida). Acta Protozool. 54: $107-122$

James M. R., Burns C. W., Forsyth D. J. (1995) Pelagic ciliated protozoa in two monomictic, southern temperate lakes of contrasting trophic state: seasonal distribution and abundance. $J$. Plankton Res. 17: 1479-1500

Jang S.-W., Kwon C.-B., Shin M.-K. (2012) First records of two Spirostomum ciliates (Heterotrichea: Heterotrichida: Spirostomidae) from Korea. Anim. Syst. Evol. Divers. 28: 29-35

Jørgensen B. B., Kuenen J. G., Cohen Y. (1979) Microbial transformations of sulfur compounds in a stratified lake (Solar Lake, Sinai). Limnol. Oceanogr. 24: 799-822
Laybourn J., Finlay B. J. (1976) Respiratory energy losses related to cell weight and temperature in ciliated protozoa. Oecologia 24: 349-355

Laybourn-Parry J., Olver J., Rees S. (1990) The hypolimnetic protozoan plankton of a eutrophic lake. Hydrobiologia 203: 11-19

López-Ochoterena E. (1966) Ciliados mesosapróbicos de Chapultepec (Sistemática, morfología, ecología). Rev. Soc. Mex. Hist. Nat. 26: 115-246

Macek M., Alcocer J., Lugo-Vázquez A., Martínez-Pérez M. E., Peralta-Soriano L., Vilaclara-Fatjó G. (2009) Long term picoplankton dynamics in a warm-monomictic, tropical high altitude lake. J. Limnol. 68: 183-192

Madoni P. (1990) The ciliated protozoa of the monomictic Lake Kinneret (Israel): species composition and distribution during stratification. Hydrobiologia 190: 111-120

Madoni P. (1991) Community structure and distribution of ciliated Protozoa in a freshwater pond covered by Lemna minor. Ital. J. Zool. 58: 273-279

Massana R., Pedrós-Alió C. (1994) Role of anaerobic ciliates in planktonic food webs: abundance, feeding, and impact on bacteria in the field. Appl. Environ. Microbiol. 60: 1325-1334

Modenutti B. E., Balseiro E. G., (2002) Mixotrophic ciliates in an Andean lake: dependence on light and prey of an Ophrydium naumanni population. Freshwater Biol. 47: 121-128

Montagnes D. J. S., Lynn D. H. (1993) A quantitative protargol stain (QPS) for ciliates and other protists. In: Handbook of Methods on Aquatic Microbial Ecology (Eds. P. F. Kemp, B. F. Sherr, E. B. Sherr, J. J. Cole). Lewis Publishers, New York, 229-240

Neidl F. (1989) Die räumliche und zeitliche Verteilung des Ciliaten Spirostomum teres im Benthal und Pelagial des Piburger Sees (Tirol, Österr.) während und nach der Sommerschichtung. Master Thesis, Universität Innsbruck, Austria

Oikonomou A., Filker S., Breiner H. W., Stoeck T. (2015) Protistan diversity in a permanently stratified meromictic lake (Lake Alatsee, SW Germany). Environ. Microbiol. 17: 2144-2157

Oikonomou A., Pachiadaki M., Stoeck T. (2014) Protistan grazing in a meromictic freshwater lake with anoxic bottom water. FEMS Microbiol. Ecol. 87: 691-703

Padisák J., Barbosa F., Koschel R., Krienitz L. (2003) Deep layer cyanoprokaryota maxima in temperate and tropical lakes. Arch. Hydrobiol. Spec. Iss. Adv. Limnol. 58: 175-199

Pajares S., Merino-Ibarra M., Macek M., Alcocer J. (2017) Vertical and seasonal distribution of picoplankton and functional nitrogen genes in a high-altitude warm-monomictic tropical lake. Freshwater Biol. 62: 1180-1193

Peštová D., Macek M., Martínez-Pérez M. E. (2008) Ciliates and their picophytoplankton-feeding activity in a high altitude warm-monomictic saline lake. Europ. J. Protistol. 44: 13-25

Porter K. G., Feig Y. S. (1980) The use of DAPI for identifying and counting aquatic microflora. Limnol. Oceanogr. 25: 943-948

Psenner R., Schlott-Idl K. (1985) Trophic relationships between bacteria and protozoa in the hypolimnion of a meromictic mesotrophic lake. Hydrobiologia 121: 111-120

Rossberg M., Wickham S. A. (2008) Ciliate vertical distribution and diel vertical migration in a eutrophic lake. Fundam. Appl. Limnol. 171/1: $1-14$

Sánchez-Medina X., Macek M., Bautista-Reyes F., Perz A., Bonilla-Lemus P., Chávez-Arteaga M. (2016) Inter-annual ciliate distribution variation within the late stratification oxycline in a monomictic lake, Lake Alchichica (Mexico). J. Limnol. 75: 179-190 
Sarmento H. (2012) New paradigms in tropical limnology: the importance of the microbial food web. Hydrobiologia 686: 1-14

Şenler N. G., Yildiz İ. (2004) Faunistic and morphological studies on ciliates (Protozoa, Ciliophora) from a small pond, with responses of ciliate populations to changing environmental conditions. Turk. J. Zool. 28: 245-265

Shazib S. U. A., Vd'ačný P., Kim J. H., Jang S. W., Shin M. K. (2016) Molecular phylogeny and species delimitation within the ciliate genus Spirostomum (Ciliophora, Postciliodesmatophora, Heterotrichea), using the internal transcribed spacer region. Mol. Phylogenet. Evol. 102: 128-144

Shazib S. U. A., Vd’ačný P., Slovák M., Gentekaki E., Shin M. K. (2019) Deciphering phylogenetic relationships and delimiting species boundaries using a Bayesian coalescent approach in protists: A case study of the ciliate genus Spirostomum (Ciliophora, Heterotrichea). Sci. Rep. 9: 16360 https://doi.org/10.1038/ s41598-019-52722-4

Sherr E. B., Sherr B. F. (1993). Protistan grazing rates via uptake of fluorescently labeled prey. In: Handbook of Methods on Aquatic Microbial Ecology (Eds. P. F. Kemp, B. F. Sherr, E. B. Sherr, J. J. Cole). Lewis Publishers New York, 695-701

Šimek K., Bobková J., Macek M., Nedoma J. (1995) Ciliate grazing on picoplankton in a eutrophic reservoir during the summer phytoplankton maximum: a study at the species and community level. Limnol. Oceanogr. 40: 1077-1090

Skibbe O. (1994) An improved quantitative protargol stain for ciliates and other planktonic protists. Arch. Hydrobiol. 130: 339347
Specht H. (1934) Aerobic respiration in Spirostomum ambiguum and the production of ammonia. J. Cell. Comp. Physiol. 5: 319-333

Straškrabová V., Callieri C., Cruz-Pizarro L., Hartman P., Macek M., Nedoma J., Šimek K. (1999) Investigations on microbial food webs in mountain lakes - aims and methods. In: Pelagic Food Web in Mountain Lakes. Mountain Lakes Research Program (Eds. V. Straškrabová, C. Callieri, J. Fott) J. Limnol. 58: 77-87

Tarbe A. L., Unrein F., Stenuite S., Pirlot S., Sarmento H., Sinyinza D., Descy J. P. (2011) Protist herbivory: a key pathway in the pelagic food web of Lake Tanganyika. Microb. Ecol. 62: 314-323

Tirjaková E., Krajčovičová K., Illyová M., Vd’ačný P. (2016) Interaction of ciliate communities with cyanobacterial water bloom in a shallow, hypertrophic reservoir. Acta Protozool. 55: 173188

Yasindi A. W., Taylor W. D. (2016) The Protozoa of soda lakes in East Africa. In: Soda Lakes of East Africa (Ed. M. Schagerl), Springer International Publishing Switzerland, 179-204

Weisse T. (2014) Ciliates and the rare biosphere - Community ecology and population dynamics. J. Euk. Microbiol. 61: 419-433

Received on $2^{\text {nd }}$ January, 2020; revised on $8^{\text {th }}$ April, 2020; accepted on $23^{\text {rd }}$ April, 2020 